\title{
A Review: On Smart Materials Based on Some Polysaccharides; within the Contextual Bigger Data, Insiders, "Improvisation" and Said Artificial Intelligence Trends
}

\author{
Serge Rebouillat ${ }^{1}$, Fernand Pla $^{2}$ (]) \\ ${ }^{1}$ Currently with DuPont Int. Op., European Headquarter, Geneva, Switzerland \\ ${ }^{2}$ Laboratory of Reactions and Process Engineering, University of Lorraine, Nancy, France \\ Email: sergereb@yahoo.com
}

How to cite this paper: Rebouillat, S. and Pla, F. (2019) A Review: On Smart Materials Based on Some Polysaccharides; within the Contextual Bigger Data, Insiders, "Improvisation" and Said Artificial Intelligence Trends. Journal of Biomaterials and Nanobiotechnology, 10, 41-77.

https://doi.org/10.4236/jbnb.2019.102004

Received: February 14, 2019

Accepted: April 1, 2019

Published: April 4, 2019

Copyright $\odot 2019$ by author(s) and Scientific Research Publishing Inc. This work is licensed under the Creative Commons Attribution International License (CC BY 4.0).

http://creativecommons.org/licenses/by/4.0/

\begin{abstract}
Smart Materials are along with Innovation attributes and Artificial Intelligence among the most used "buzz" words in all media. Central to their practical occurrence, many talents are to be gathered within new contextual data influxes. Has this, in the last 20 years, changed some of the essential fundamental dimensions and the required skills of the actors such as providers, users, insiders, etc.? This is a preliminary focus and prelude of this review. As an example, polysaccharide materials are the most abundant macromolecules present as an integral part of the natural system of our planet. They are renewable, biodegradable, carbon neutral with low environmental, health and safety risks and serve as structural materials in the cell walls of plants. Most of them are used, for many years, as engineering materials in many important industrial processes, such as pulp and papermaking and manufacture of synthetic textile fibres. They are also used in other domains such as conversion into biofuels and, more recently, in the design of processes using polysaccharide nanoparticles. The main properties of polysaccharides (e.g. low density, thermal stability, chemical resistance, high mechanical strength...), together with their biocompatibility, biodegradability, functionality, durability and uniformity, allow their use for manufacturing smart materials such as blends and composites, electroactive polymers and hydrogels which can be obtained 1) through direct utilization and/or 2) after chemical or physical modifications of the polysaccharides. This paper reviews recent works developed on polysaccharides, mainly on cellulose, hemicelluloses, chitin, chitosans, alginates, and their by-products (blends and composites), with the objectives of manufacturing smart materials. It is worth noting that, today, the fundamen-
\end{abstract}


tal understanding of the molecular level interactions that confer smartness to polysaccharides remains poor and one can predict that new experimental and theoretical tools will emerge to develop the necessary understanding of the structure-property-function relationships that will enable polysaccharide-smartness to be better understood and controlled, giving rise to the development of new and innovative applications such as nanotechnology, foods, cosmetics and medicine (e.g. controlled drug release and regenerative medicine) and so, opening up major commercial markets in the context of green chemistry.

\section{Keywords}

Polysaccharides, Cellulose, Hemicelluloses, Chitosan, Alginate, Composites, Blends, Hydrogels, Smart Materials, Electro-Active Papers, Sensors, Actuators, Bigger Data, Innovation, Science in Education, Jazz, 4C, CRAC

\section{Introduction}

\subsection{Prelude}

"The use of biomaterials for industrial applications has increased significantly. Carbon footprints rationalization and food vs. fuel dilemma have been debated and made considerable progress towards a wider acceptance at various levels. Open innovation contributes meaningfully with regards to: softer, milder temperature biochemical processing which includes preconditioning, low stress reactions, "just-as-needed" purifications, zero waste, fallow land exploitation rationalization, usable agri-waste, traceable land use, water consumption minoration vs. agronomical food-related practice, partial detachment from international seasonal trading of agricultural commodities..." [1].

In this context, our journey across the "rurban" zones is evolving. The sightseeing is a planet "responsible" fairytale that is coming closer to reality; locally produced, synergically codependent energies. Piezo (due for example to the unique crystalline structure and piezoelectric behavior of cellulose as described later in Section 2.2) and solar photovoltaic road paving, quietly growing $\mathrm{CO}_{2}$ harvesting forests, prairie and golden fields ecofuel providers... are among the multi centennial castles, monuments and mills now wind, solar and hydraulic universal converters.

Along this fairy trail, alternative energies (Figure 1), as well as new energy usage patterns are promoting innovation in the field of energies' production, transmission, transformation, distribution and local usages.

"The emotional intelligence has become a recognized essential part of a global 'balance', in this virtual-reality." Let's see what we said some about 20 years ago, on related skills [2].

"Can we foresee the profile of the next generation of scientists and engineers? The people behind innovation are essential to establish the foundations of the 

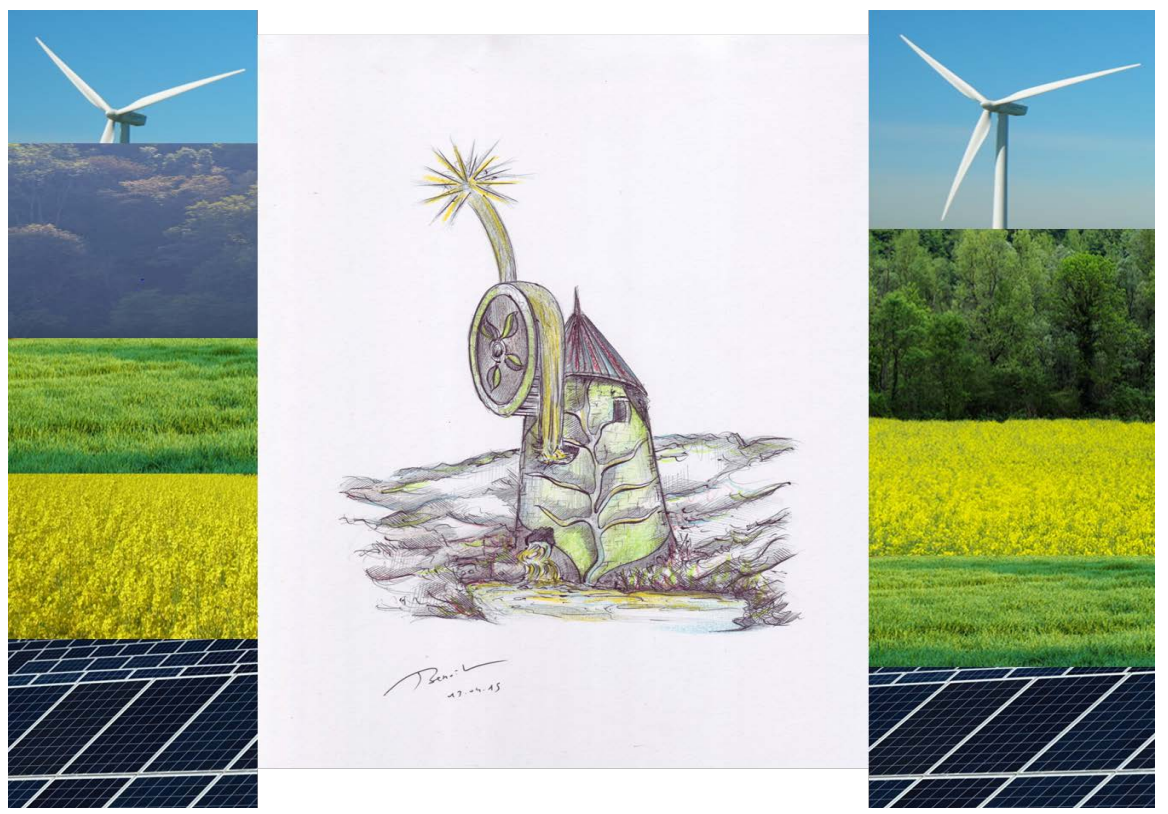

Figure 1. Alternative Energy Illustration designed with author's private art: wind turbines and photovoltaic solar \& piezo factories among golden canola fields with forests in the background and centrally, "inspirationally redesigned" old wind mill [1].

future successful businesses. In the chemical industry, the chemist, the physicist, the material scientist, the engineers are playing an important role in the creative process which is required to follow the pace of change. New organizational concepts have been proposed in order to schematize the industry adaptation to this 'new' global environment. We found that most of them require from the people a balance of skills which we propose to abbreviate with the acronym $4 \mathrm{C}$, where the 4Cs represent: Connaissance, Creativity, Competence, Communication. 'Pursuing with', the bubble concept is one way of stimulating innovation. It is possible to combine enterprises or projects $\mathrm{A}, \mathrm{B}, \mathrm{C}$ in a way that the mentors, the promoters, the generators of the enterprise $\mathrm{A}$ have a chance to play another role in B or in C...”.

Figure 2 below helps capture more about the above $4 \mathrm{C}$ innovative tetralogy.

The number of current innovation styles, from open to close, disruptive, collaboratory ${ }^{\oplus}$, from reverse to inclusive, nested and frugal, are more or less self-explanatory terminologies and further enlightenment can be found, e.g. in Lapray et al. [3] [4] in reviews on the matter, covering some of them [5].

More literature on artistic creation and more expressly musical art is dedicated to the innovation traits of musical production, rather say improvisation; Jazz is of an established relevance.

Figure 3 attempts to provide the 4 C's corresponding Jazz terms and concepts therewith developed by the expert Charles Calamel [6], in the creation, integration, self learning and improvisation model that Jazz culture continues to develop spontaneously.

One may further cite Charkes Calamel proposed acronym "CRAC" [6], with stands for Competent, Responsible, Autonomous, Creative... definitely a series 


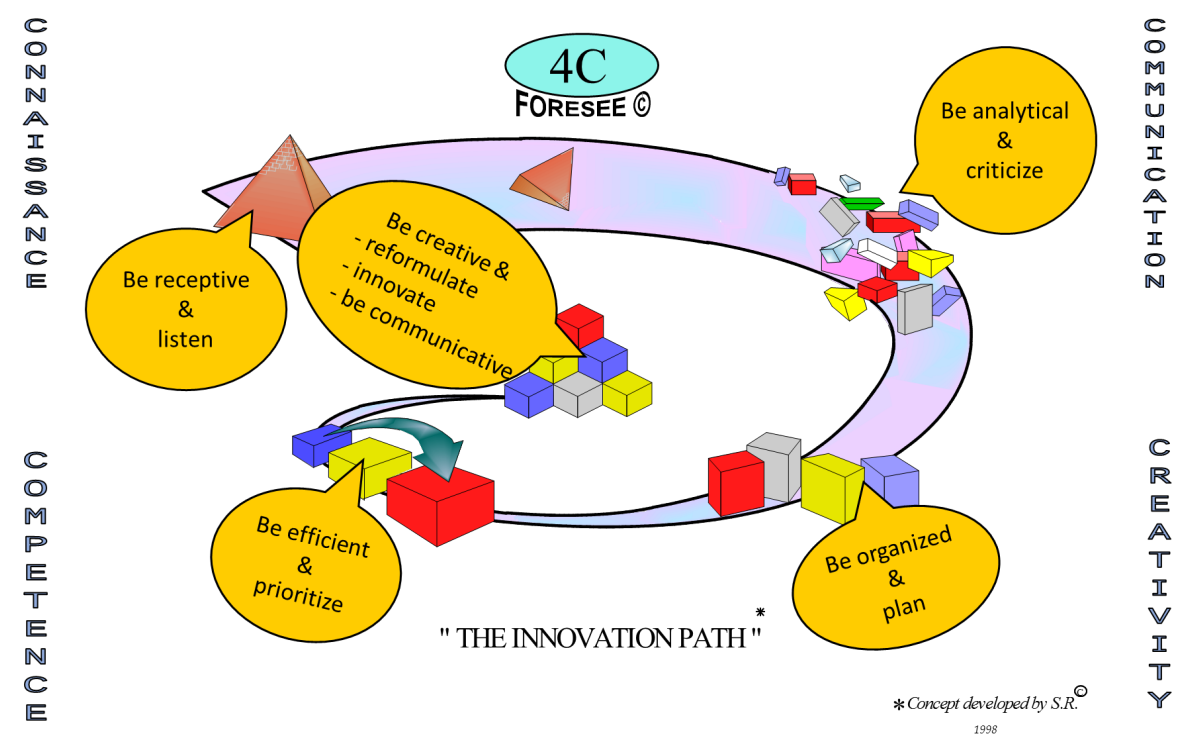

Figure 2. "Foresee, 4C, the innovation path" [2].

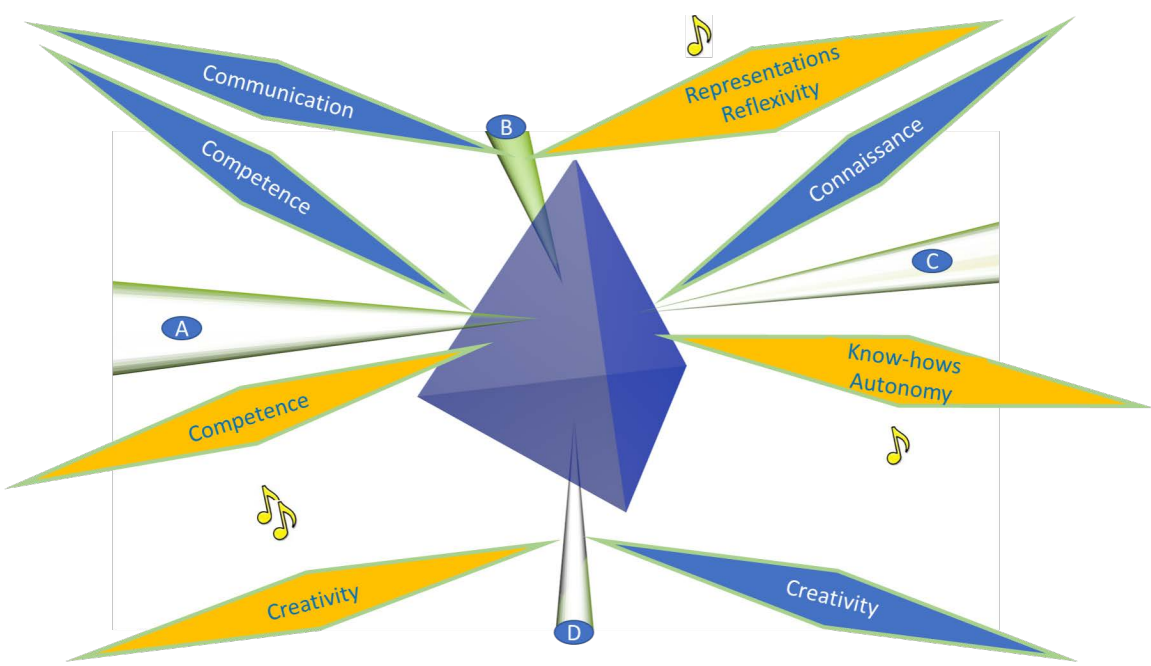

Figure $3.4 \mathrm{C}^{\oplus}$ concepts in blue diamonds of Figure 2 compared with the Jazz tetrahedral representation of [6], in yellow diamonds.

of traits that innovation in the bigger data surrounding cannot miss.

Charles Calamel, (http://www.touteduc.fr/fr/archives), says: "Jazz is a model in that it leads the individual towards a self-direction in learning, a construction of oneself. Due to the conditions of play, the respect and transgression of codes and formats, jazz reverses the traditional pedagogic guidance system to set up a model of autonomy: it is not a question of receiving knowledge but rather of 'Go find it" ".

Fred Hersch's song title "Songs without Words" may further highlight the improvisation nature and emotional intelligence of creativity and innovation.

Emotional intelligence which may become more central to diversity innovative approach, to capture developmental potential, may not fit within the trend of bigger data and artificial intelligence interaction; although the later may be a 
source of improvisation.

In that domain D. Lapray and S. Rebouillat [3] presented some anticipatory aspects in a review: “'Bigger Data' Visualization to Visual Analytics: a path to Innovation. 'Happening, definitely! Misleading, possibly?' A review of some examples applicable to IP Discovery." The authors pointed out that aesthetic may be privileged and can be misleaded. Figure 4 below is a clear demonstration.

In Figure 4, out of [3], "the same analysis was applied to the title of 1000 patents in the field of natural polymers. The 13 top nodes are displayed using the Kamada-Kawai layout (well known force-directed graphs). The three panels represent the exact same data on which the layout was reinitialized three consecutive times. Note that only the nodes, edges size and color are maintained between these three representations. These are the only relevant information, the rest being purely aesthetical."

No need to be a professional in the advertisement arena or a malicious developer, of fake impression carried by photography angle shot selections, to realize that the above triangles configurations of Figure 4, with bold solid heavy black sides, although linking the same matters, Composit (es)-Fiber (s)-Materi (als) \& (Polym (ers)) may, take different dimension pending on the persons observing these figures, their mindset of the time.

There is indeed an improvising dimension that may arise from bigger data analysis and visualization. Such as the representation on the left side may give a sharp and central dimension of the three first matters of Composit (es)-Fiber (s)-Materi (als)-(Polym (ers)), the central representation may imply a massive bulk dimension of the four, and the representation on the right may elude to a side lateral importance of the three first. Analogically the jazz player may improvise some mimics and positionings that will attract attention on some elements of his production and interactions.

The improvision dimension of innovation is certainly a way to liberate the creator away from core dimensions; those are prevalent and revealed in patent analysis wherein a language rarely changes as long as it is in the core corporate language and know hows. Laterals and boundaries are efficient add-ons in an inventive concept presentation.

In a nutshell, the parallel between innovation and art has been progressively
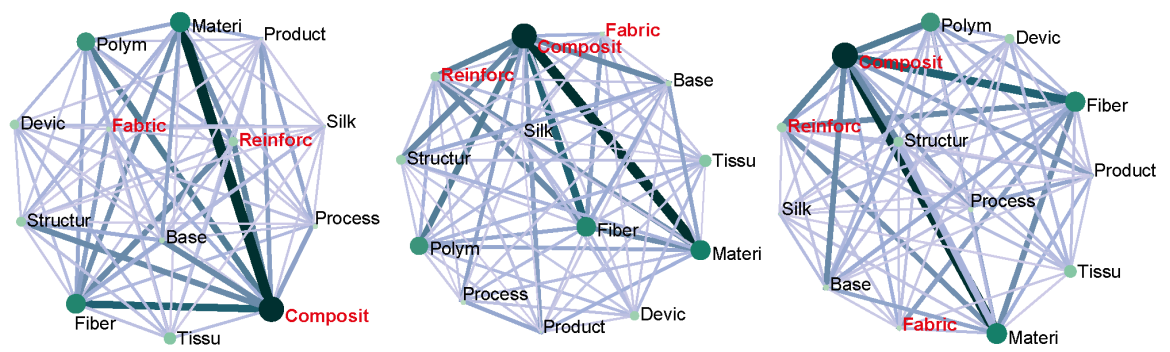

Figure 4. Aesthetical tricks do not necessary carry relevant information. The same analysis was applied to the title of 1000 patents in the field of natural polymers. 
brought to the attention of the reader from a fairy tale landscape making innovative use of natural resources keeping "monuments in place". Followed by the foresee, "4C", dimension of the collaborative skills developed back in 1998 by Rebouillat. Extended to the Jazz science to education breadth and its self-learning integration value; associated with a high degree of intrinsic improvision. Closing the loop with the bigger data and artificial intelligence emotional limitations and potential for misleadingness that may deserve a longer propos in a review to come.

Instinctive and improvisional innovations are to be added on the list of [4].

Additional references on the above fields with selected technology domains are useful [7]-[13].

\subsection{More Centrally}

The present paper follows up on three reviews [14] [15] [16] that we published on important researches related to the valorization of biomaterials, one of them [14] reached record downloads of 10,500 and 17,500 views, which supports the interest for scientific expert reviews in the context of bigger data; obviously big data consolidation can still improve to be even more useful to the "trained in the art".

Smart or functional materials form a group of new and state of art materials now being developed that will have a significant influence on many of present-day technologies. Also called active materials, smart materials have the intrinsic and extrinsic capabilities, first, to respond to stimuli and environmental changes and to activate their functions according to these changes [17] [18]. The stimuli could originate internally or externally. Examples of external stimuli can be temperature, pressure, electric and magnetic fields, chemicals, light, humidity, hydrostatic pressure, nuclear radiation, $\mathrm{pH}$ and more. Smart material responds to those stimuli with changes in their internal structure and intrinsic properties such as shape, stiffness, viscosity, energy absorption capacity, damping or optical properties like transparency or opacity.

Most smart materials have reversible properties, reverting back to their original state after the stimulus is removed or changed. The cycle can then be repeated. Smart materials are also tailorable and tunable, which means they can be designed for specific, controlled property changes. To achieve a specific objective for a particular function or application, a new material has to satisfy specific qualifications related to technical and technological properties, economic criteria, raw material and production costs, supply expenses and availability, environmental characteristics and sustainable development criteria, implying reuse and recycling capacities.

If the functions of sensing and actuation are added to this list, the new material is considered a smart material [19]. Since the 1990s, a lot of research efforts have been devoted to the development [20] [21] [22] and industrial application [23] [24] of smart materials. Examples of some well-known smart materials are piezoelectric polymers [25], piezoelectric ceramics [26], shape memory alloys 
[27], electro-active polymers [28], covalent adaptive network polymers [22] and electrorheological and magneto rheological fluids [29].

Many other materials with added functions: have also been developed. They concern 1) sensor materials to detect certain signals, adjust sensitivity according to environmental changes, or restore degraded sensitivity, 2) catalytic materials to detect the progress of a reaction or distinguish the reaction of a product, 3) textile materials to detect a variety of signals from the human body and weather conditions so as to allow for greater comfort.

Smart composite materials: are also manufactured by combining two or more single smart materials in order to utilize synergistically the best properties of their individual constituents. Many of those composites are able to satisfy all of the above specific qualifications. Their advantages and adaptability to the design requirements mentioned above have led to a profusion of new products. There are two essential types of smart composite materials 1) completely tailored man-made composite materials which purpose is to improve or add strength or stiffness, 2) amalgamation of single/composite materials with fibre/reinforced polymers (FRPs) such as the ones used as reinforcement for concrete, steel or other construction materials. If the FRP is combined with fibre optic sensors, the resulting product will be an attractive and particularly cost effective smart composite.

A smart structure is a system that incorporates particular functions of sensing and actuation to perform smart actions in an ingenious way. It is composed of the following components:

- Data Acquisition (tactile sensing) which collects the required raw data needed for an appropriate sensing and monitoring of the structure.

- Data Transmission (sensory nerves) to forward the raw data to the local and/or central command and control units.

- Command and Control Unit (brain) which manages and controls the whole system by analyzing the data, reaching the appropriate conclusion, and determining the actions required.

- Data Instructions (motor nerves) which transmits the decisions and the associated instructions back to the structure.

- Action Devices (muscles) which take action by triggering the controlling devices/units.

The Main areas of R\&D involved in smart materials are:

- For sensors and actuators: photo-sensitive materials, fibre optics, conductive polymers, thermally sensitive materials, shape memory materials, intelligent coating materials, chemical responsive materials, micro-capsules, microand nano-materials.

- For signal transmission, processing and control: neural networks and control systems, cognition theory and systems.

- For integrated processes and products. wearable electronics and photonics, adaptive and responsive structures, bio-mimics, tissue engineering, chemi- 
cal/drug releasing.

Figure 5 summarizes how does a smart material works.

In the last ten years, the field of smart materials has received much attention as a result of the development of new electro-active polymer (EAP) materials that exhibit a large displacement displacement response which changed the potential capability and paradigms of these materials. The main attractive characteristic of EAP is their operational similarity to biological muscles, particularly their resilience and ability to induce large actuation strains [30]. This characteristic is a valuable attribute that has enabled a myriad of potential applications, and it has evolved to offer functional similarity to biological muscles. EAP materials are able to offer a range of performance and characteristics that may not be reproduced by other technologies. Therefore, it is rather certain that EAP materials have a promising future for applications, such as biologically inspired actuators driving various mechanisms for manipulation and mobility including micro-robots, micro-flying objects, and animatronic devices.

Today, the focus is on specialty products engineered for specific end-uses and on creative ways to market these products and the current generation of smart materials has many new dynamic features that enable them to adapt to the environment and make them the materials of the future, mainly, as this will be further outlined in this paper, in the domain of renewable biomass-materials.

The present paper follows upon three reviews [14] [15] [16] that we published on important researches related to the valorization of polysaccharides with the objectives of reducing the fossil resource dependence and producing therefore environmentally-friendly new materials. Indeed, the great biodiversity of nature (i.e., plants, animals, insects, enzymes, microbes, etc.) coupled with the enormous advances developed in biotechnological processes, makes it today possible, through adequate transformations of bio-sourced products, to elaborate high

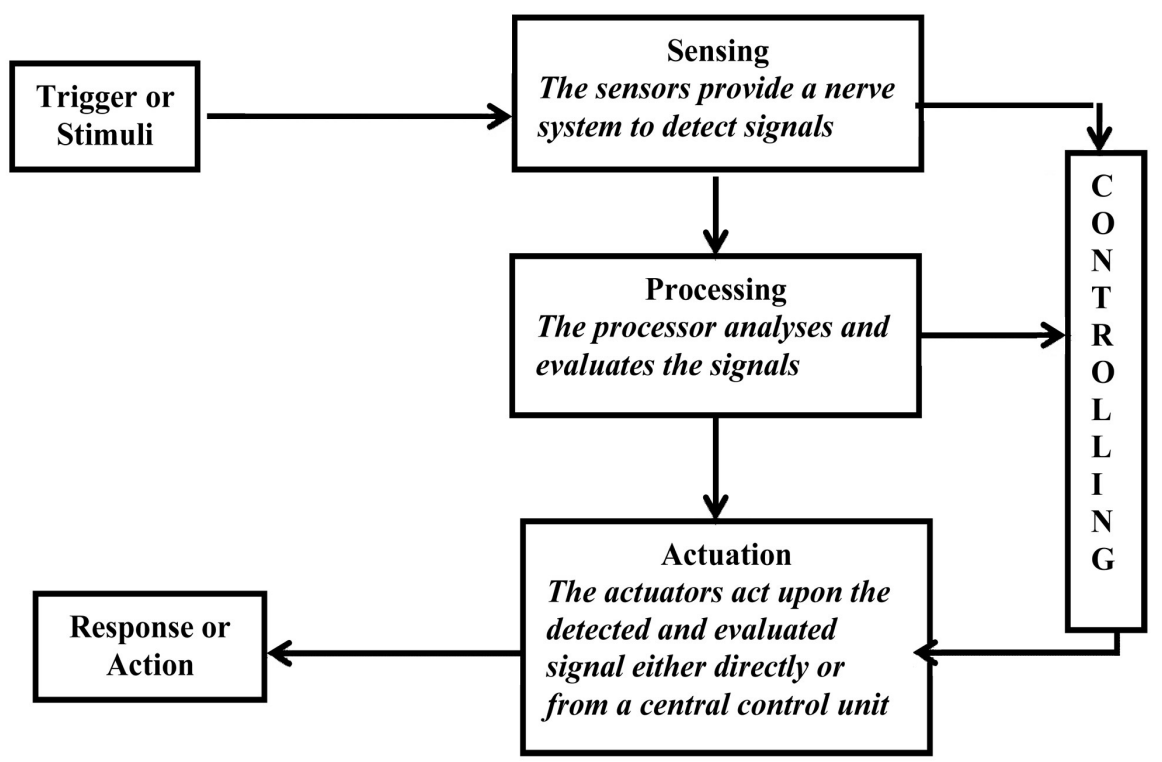

Figure 5. General presentation of smart material actions. 
value-added sustainable products endowed with physical, chemical and biological properties leading to particularly innovative applications.

This paper reviews recent works developed on those natural resources with the objectives of manufacturing smart materials. The biosourced products which will be considered are polysaccharides, including cellulose, hemicelluloses, chitin, chitosan, alginates, and their by-products (copolymers, blends and composites).

Polysaccharides are the most abundant materials that can be obtained from renewable and sustainable resources. They are biodegradable, carbon neutral with low environmental, health and safety risks and serve as structural material in the cell walls of plants. Some of them (e.g. cellulose and hemicelluloses) are used, for many years, as engineering material in many industrial processes such as pulp and papermaking and manufacture of synthetic textile fibres (e.g. organic and inorganic esters, alkyl, hydroxy alkyl and carboxyl alkyl ethers) which are important components in coatings, optical films, foodstuffs, pharmaceutics, cosmetics, additives in building materials, etc. [14].

Moreover, owing to polysaccharides properties, functionality, durability and uniformity, their use continue today in other domains (e.g. conversion into biofuels such as ethanol as an alternative fuel source and, more recently, in the design of processes using polysaccharide nanoparticles for the generation of novel polysaccharide-based biomaterials and composites [14]).

On the other hand, it is noteworthy that chemical modifications of polysaccharides, "tailor-made" towards specific properties can also result in new materials, including smart materials. Indeed, owing to their unique and valuable functional properties, modified polysaccharides can confer smartness through somewhat unique mechanisms such as:

- reversible, stimuli-responsive self-assembly (gelation),

- biospecific interactions with enzymes and lectins (carbohydrate-binding proteins)

- And interactions that confer nanoscale (e.g. fibril-forming) and hierarchical supramolecular assembly.

Nevertheless, today, the fundamental understanding of the molecular level interactions that confer smartness to polysaccharides remains relatively poor and one can predict that new experimental and theoretical tools will emerge to develop the necessary understanding of the structure-property-function relationships that will enable polysaccharide-smartness to be better understood and controlled, giving rise to the development of new and innovative applications. This would allow making polysaccharides materials of choice in the very promising areas of nanotechnology, foods, cosmetics and medicine (e.g. controlled drug release [31] and regenerative medicine [32] [33]) and so, opening up major commercial markets in the context of green chemistry.

\section{Cellulose-Based Smart Materials}

Cellulose is the major constituent of the plants cell walls [34] [35]. It has many prominent properties such as high modulus and tensile strength, excellent me- 
chanical strength, hydrophilicity, biocompatibility, biodegradability and relative thermal-stability [36] [37].

Cellulose is a linear syndiotactic homopolymer composed of

$D$-anhydroglucopyranose units which are linked by $\beta$ - $(1 \rightarrow 4)$-glycosidic bonds (Figure 6).

The high content of hydroxyl groups along the skeleton of cellulose, is the basis of an extended system made of intra- and inter-molecular hydrogen bonds allowing the formation of highly ordered, three-dimensional crystal structures, making cellulose a semi-rigid polymer made of elementary microfibrils with two structure regions: the crystalline region and the amorphous region [38].

\subsection{Cellulose Nanofibers and Nanoparticles}

Despite its high hydroxyl groups content, cellulose has limited functionalities and, to our knowledge, there are very few reviews on "smart" materials based on cellulose unless hydrogels which were referred to [39] [40] [41]. Nevertheless, the physical structures of cellulose fibers, (particularly cellulose nanofibers. $C N F s$ ) and nanoparticles (nanocelluloses. $C N C s$ ), have opened up interesting opportunities to manufacture blends and composites used to make high valued products (Table 1 ).

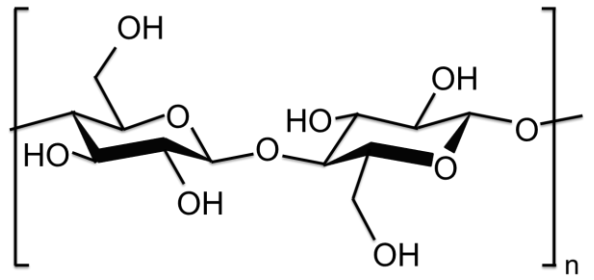

Figure 6. Chemical structure of cellulose.

Table 1. High value cellulose nanofiber and nanoparticle smart materials and corresponding potential applications.

\begin{tabular}{|c|c|c|c|}
\hline Type of cellulose & Fabricated material & Potential application & Reference \\
\hline Nanofiber & $\begin{array}{l}\text { Optically Transparent } \\
\text { Nanofiber Paper }\end{array}$ & Flexible circuits & [47] \\
\hline Nanofiber & Transparent nanocomposites & Electronics device industry & {$[48]$} \\
\hline Nanofiber & $\begin{array}{l}\text { Transparent cellulose-based } \\
\text { nanocomposites }\end{array}$ & Solar panels & {$[47]$} \\
\hline Nanocellulose & $\begin{array}{c}\text { Antibiotics/Carbonated } \\
\text { hydroxyapatite coatings on titanium }\end{array}$ & Implant materials & [49] \\
\hline Nanocellulose & Scaffold materials & Cartilage tissue engineering & {$[50]$} \\
\hline $\begin{array}{c}\text { Bacterial } \\
\text { nanocellulose (BNC) }\end{array}$ & Scaffold materials & Tissue engineering & {$[51]$} \\
\hline $\begin{array}{c}\text { Bacterial } \\
\text { nanocellulose (BNC), }\end{array}$ & BNC membranes & $\begin{array}{l}\text { Biomedical applications } \\
\text { (drug delivery, cytotoxicity } \\
\text { against cancer cells) }\end{array}$ & {$[52]$} \\
\hline $\begin{array}{l}\text { Carboxymethylcellulose } \\
\text { (CMC) }\end{array}$ & Spherical CMC nanoparticles & Biomedical applications & [53] \\
\hline
\end{tabular}


CNFs photo-responsive nature can act as adaptive fillers in soft polymer matrices. CNCs properties such as low density, thermal stability, chemical resistance, high mechanical strength, biocompatibility and biodegradability allowed to consider them as functional materials in actuation systems and sensors for detecting $\mathrm{pH}$, organic vapors, ions and humidity [39] [42].

CNC based smart materials display intelligent behavior in response to environmental stimuli such as light, temperature, electrical input, $\mathrm{pH}$, and magnetic force [43] [44] [45]. Moreover, owing to their high aspect ratio and mechanical properties, CNCs can also serve as renewable reinforcing agents in nanocomposites, as well as a handle for adding stimuli responsiveness [46].

On the other hand, the properties of cellulose enable cellulose to be applied to the vast fields of smart electroactive polymers and hydrogels which can be fabricated through chemical modifications or physical incorporating/blending processes.

Chemical modifications of cellulose are realized using homogeneous or heterogeneous processes.

Homogeneous processes are mainly carried out by dissolution of cellulose derivatives (e.g. carboxymethyl cellulose (CMC), hydroxypropyl cellulose (HPC), hydroxyethyl cellulose (HEC), and cellulose acetate (CA)) in suitable solvents (e.g. water or common organic solvents).

Heterogeneous processes are usually performed, after swelling in suitable solvents, on cellulose nanocrystals (CNCs), films/membranes, fibers, and cellulose particle suspensions.

In the processes of physical incorporating/blending, cellulose or cellulose derivatives act as matrices, fillers, or coatings/shells [15].

\subsection{Cellulose Electroactive Paper}

Recently, cellulose has been discovered as a smart material named cellulose-based electroactive paper (EAPap) [54] [55] [56] [57]. The electroactive behavior of EAPap is due to the unique crystalline structure and piezoelectric behavior of cellulose [58]. Indeed, cellulose II crystal is monoclinic and non-centrosymmetric in nature and thus it exhibits piezoelectric characteristics [54] [59] [60]. This piezoelectricity is able to induce large displacement output, low actuation voltage, and low electrical power consumption in the application of biomimetic sensors/actuators and electromechanical system.

Moreover, nanocellulose-based EAPap portrayed several superior characteristics such as ultra-lightweight, large bending deformation, low actuation voltage and low power consumption. These characteristics are very appealing for delicate biomimetic actuators and sensors, dynamic wings for flying articles, active sound-absorbing materials, adaptable speakers and smart shape control gadgets [56] [61] (Table 2).

In addition, preparation of nano-cellulose-based smart material via chemical modification and physical incorporation or blending in various forms can affect 
Table 2. Potential applications of EAPap actuators.

\begin{tabular}{ccc}
\hline EAPap characteristic/quality & Potential application & Reference \\
\hline Low electrical power consumption & Microwave-driven actuators & {$[62]$} \\
Biocompatible and hydrophilic properties & Biosensors & {$[63][64]$} \\
Microwave-driven innovations & $\begin{array}{c}\text { Controlled actuators, } \\
\text { Biomimetic robots }\end{array}$ & {$[65]$} \\
Reasonable quality & Vibration sensors & {$[66][67]$} \\
Acoustic characteristics & Acoustic applications & {$[67]$} \\
Stacked and unimorph EAPap actuator & Haptic applications & {$[68]$} \\
Piezoelectric paper & EAPap speakers & {$[69][70]$} \\
Ultra-lightweight and consumption of less & Microscale robotic insects, & \\
energy $\geq$ response to electrical stimulatio & Tiny flying objects, Wireless & {$[71]$} \\
& power supplies & \\
\hline
\end{tabular}

responsiveness to $\mathrm{pH}$, temperature, light, mechanical forces, electricity, and magnetic field. The presence of porosity and refractive index variation has made EAPap a feature with extraordinary light-scattering effect (used as a transparent paper) for use in integrated transparent sensors and 3D microfluidic application.

However, even if there are already many potential applications for cellulose EAPap, it must be noted that, today, several important challenges remain and should be considered, for example in terms of reliability, material robustness and force improvement.

\subsection{Cellulose Hydrogels}

Gels are three-dimensional natural or synthetic polymer networks that can swell and absorb large amounts of solvents without dissolving, provided that chemical or physical crosslinks exist among the macromolecular chains.

Hydrogels are, mainly, structures formed from biopolymers and/or polyelectrolytes, and contain large amounts of trapped water. They can be divided into chemical gels and physical gels. Chemical gels are formed by covalent bonds while physical gels are formed by molecular self-assembly through ionic or hydrogen bonds [72]. They have wide potential applications in the fields of food, biomaterials, agriculture, water purification, etc. (Table 3 ).

Responsive hydrogels can undergo a swelling transition in response to environmental stimuli, such as the changes in temperature, light, $\mathrm{pH}$, etc. Because of this unique feature, responsive hydrogels have received an extensive attention in the fields of drug delivery [82], bioseparation [83], sensors, and optical transduction of chemical signals [83] [84]. For example, the drug release from responsive hydrogels can be remotely controlled by the local heating of magnetic nanoparticles [85]. The same concept has been transferred to the application in catalytic reaction, which is particularly attractive due to the unique tunable and responsive properties as well as the improvement of reactive properties [82] [83] [84]. Specifically, the swelling and deswelling of the hydrogel with temperature 
Table 3. Examples of some classical hydrogels and corresponding applications.

\begin{tabular}{ccc}
\hline Hydrogels & Application & Reference \\
\hline Polymer blends of natural and/or synthetic polymers & Drug delivery & {$[73]$} \\
Supramolecular hydrogels & Drug delivery & {$[74]$} \\
Chitosan and Polyethylenimin & Tissue engineering & {$[75]$} \\
Natural polymers (collagene, hyaluronic acid alginate, \\
chitosan) and synthetic polymers (PEO, PEG and \\
$\begin{array}{c}\text { corresponding block copolymers with poly(lactic acid) } \\
\text { Methacrylate/acrylic acid (AA) copolymers }\end{array}$ & Tissue engineering & {$[76]$} \\
Poly(acrylic acid)/poly(vinyl alcohol) & Inverse opal & \\
pH sensors & {$[77]$} \\
GM3 material (terpolymer, based on high-purity & Piezoresistive & {$[78]$} \\
glycerol methacrylate) from Contamac, & pH sensors & \\
Nanofilm-encapsulated silicone-hydrogel & contact lenses & {$[79]$} \\
& & \\
Ni ${ }^{2+}$-poly (2-acetamidoacrylic acid) hydrogel & contact lenses & {$[80]$} \\
& Purification of & \\
& histidine-tagged green & {$[81]$} \\
\hline
\end{tabular}

change can control the loading/unloading of reactants in the hydrogel network, which, in turn, changes the reactivity.

There are plenty of methods for preparing hydrogels. The mixing of anionic and cationic polymers solutions is widely used for preparing reversible hydrogels. The final properties of the 3D network of physical hydrogel should depend on several factors such as the anionic/cationic charge ratio, the $\mathrm{pH}$ and the existence, or not, of stirring and the respective speed during the preparation, as well as several other parameters.

After these basic definitions and examples, the following paragraphs aim at highlighting some of the most recent developments in cellulose-based hydrogels materials, including pure cellulose, cellulose composite and cellulose hybrid hydrogels.

\subsubsection{Pure Cellulose-Based Hydrogels}

Two routes have been thoroughly developed for their preparation:

\section{- Direct preparation from native cellulose}

Due to its highly extended hydrogen bonded structure, native cellulose is very difficult to be dissolved in common solvents. Recently, new solvents have been developed to dissolve cellulose providing great opportunities for the preparation of cellulose hydrogels. The main solvents used for those hydrogel preparations are: $\mathrm{LiCl} /$ dimethylacetamide (DMAc), $\mathrm{N}$-methylmorpholine- $\mathrm{N}$-oxide (NMMO), Ionic liquids (ILs), Alkali/urea (or thiourea) aqueous systems.

\section{- Cellulose derivatives-based hydrogels}

Cellulose derivatives such as MC, HPC, HPMC and CMC have been used to fabricate cellulose-based hydrogels through physical and chemical cross-linking. Physical cross-linked gels are formed by ionic bondings, hydrogen bondings, or 
associative polymer-polymer interactions. Chemical cross-linked hydrogels are prepared by cross-linking two or more polymer chains with a functionalized cross-linker.

With the development of cellulose derivatives, mainly cellulose ethers, some stimuli-responsive hydrogels have been developed leading to temperature sensitive hydrogels and $\mathrm{pH}$ sensitive hydrogels from MC, HPC, HPMC and CMC.

Cellulose-based hydrogels have many favorable properties such as hydrophilicity, biodegradability, biocompatibility, transparency, low cost, and non-toxicity. Therefore, cellulose-based hydrogels have many applications (Table 4).

\subsubsection{Cellulose-Polymers Composite Hydrogels}

Cellulose (or its derivatives) has been blended with both natural biodegradable polymers and synthetic polymers. Combining the different properties of cellulose and other polymers has given rise to novel hydrogel smart materials with specific applications. Various composite hydrogels were designed in wide size from macroscopic materials such as membranes, fibers, and beads to microscopic materials such as microgels, and nanogels (Table 5).

Table 4. Examples of cellulose-based hydrogels and their applications.

\begin{tabular}{ccc}
\hline Cellulose-based hydrogel & Application & Reference \\
\hline Si-HPMC & Tissue engineering & {$[86]$} \\
Na-CMC and cellulose & Controllable delivery systems & {$[87]$} \\
Cellulose acetate and phospholipids & Blood purification & {$[88]$} \\
Crosslinked (HEC) and (CMC) & Sensors and actuators & {$[89]$} \\
CMC/Acrylamide & Super absorbents for agriculture & {$[90]$} \\
Poly[(N-tert-butylacrylamide)-co-acrylamide]/ & and horticulture & {$[91]$} \\
HPC & Swelling temperature-sensitive & agents \\
Cellulose/chitin beads & Water purification & {$[92]$} \\
Regenerated cellulose beads \\
modified with silane
\end{tabular}

Table 5. Examples of cellulose-polymers composite hydrogels.

\begin{tabular}{ccc}
\hline Cellulose-polymers composite hydrogels & Application & Reference \\
\hline CMC/Chitosan & Cells immobilization & {$[94]$} \\
$\begin{array}{c}\text { Starch/Cellulose-based polymers } \\
\text { (sodium alginate, } \mathrm{HPMC}, \mathrm{NaCMC})\end{array}$ & Thermal behaviour & {$[95]$} \\
CMC/Starch & Textile sizing and floculation agents & {$[96]$} \\
Na alginate/gelatin, and Na & Release of carbaryl & {$[97]$} \\
alginate/NaCMC blend beads & pH-sensitive hydrogels & {$[98]$} \\
Alginate/MC & Use in prevention of postsurgical & {$[99]$} \\
Hyaluronic acid/HEC; Hyaluronic acid/NaCMC & soft tissue adhesion & \\
\hline
\end{tabular}




\subsubsection{Cellulose Hybrid Hydrogels}

In recent years, polymeric-inorganic hybrid materials have attracted increasing attention due to potential applications in electric, optical, magnetic, and biological fields. Introduction of inorganics into cellulose hydrogel networks is an effective way to develop materials with high functionality. Indeed, cellulose hydrogels have been used as matrices to incorporate inorganic nanoparticles for preparing cellulose-inorganic hybrid hydrogels [100] [101] [102] [103] [104]. It is worth noting that with the development of nanotechnology, this strategy is suitable for fabricating novel cellulose-based hydrogels with multifunctional properties. The smart behaviour of some cellulose derivatives (e.g., $\mathrm{NaCMC}$, HPMC) in response to physiologically relevant variables (i.e., $\mathrm{pH}$, ionic strength, temperature) makes the resulting hydrogels particularly appealing for in vivo applications.

On the other hand, even if cellulose is known to be non-bioresorbable, it seems possible to functionalize cellulose-based hydrogels with bioactive and biodegradable extracellular matrix domains. This suggests that, in the near future, such hybrid hydrogels might constitute ideal platforms for the design of scaffolding biomaterials that could be used in the fields of tissue engineering and regenerative medicine.

\section{Hemicelluloses-Based Smart Materials}

Hemicelluloses, as natural polysaccharides, are categorized as the second most abundant components of the plants after cellulose and constitute about $20 \%$ $30 \%(w / w)$ of the total weight of the lignocellulosic biomass [34] [105]. Hemicelluloses have a random, amorphous structure. They are hetero-polymers with various chemical linkages between different monomer units such as pentoses (xylose, lyxose, arabinose, ribose...) and/or hexoses (glucose, fructose, galactose, mannose, rhamnose...). Different hemicellulose chemical compositions, structures and amounts are present in biomass. Hemicelluloses are polysaccharides that have beta- $(1 \rightarrow 4)$-linked backbones with an equatorial configuration and include mainly xyloglucans, xylans, mannans, glucomannans, galactoglucomannan, O-acetyl-(4-O-methylglucurono)-xylan, O-acetyl-galactoglucomannan etc. Figure 7 and Figure 8 show, as examples, the chemical structure of two main hemicelluloses present in hardwoods and in softwoods respectively.

It is worth noting that the pendant hydroxyl groups of the polysaccharide backbone offer a number of possibilities for the chemical modification of hemicelluloses and for the preparation of materials with new profiles that can increase the utility of these biopolymers. Several methods are applied to extract hemicelluloses from biomass (Table 6).

Increasing attention has been concentrated on the development and application of hemicellulosic products because of their numerous inherent advantages, including non-toxicity, biocompatibility, biodegradability, and anti-cancer effect [111] [112]. 


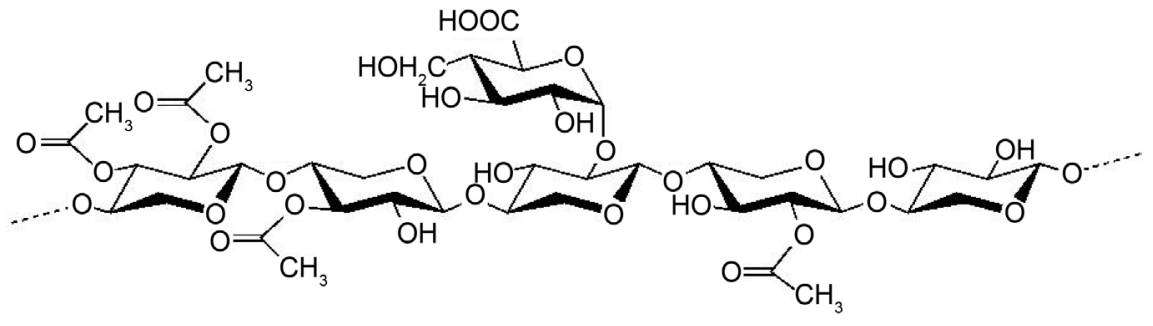

Figure 7. Main hemicellulose of hardwoods: O-acetyl-(4-0-methylgucorono)-xylan.

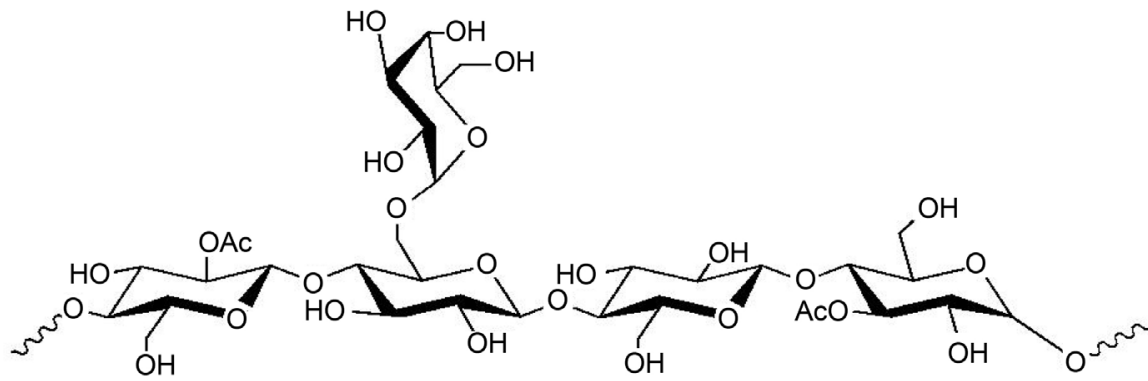

Figure 8. Main hemicellulose of softwoods: O-acetyl-galactoglucomannan (AcGGM).

Table 6. Principal methods developed to separate hemicelluloses from the other constituants of biomass.

\begin{tabular}{|c|c|c|c|}
\hline $\begin{array}{c}\text { Raw } \\
\text { material }\end{array}$ & Extraction method & Advantages/Disadvantages & Reference \\
\hline Softwood & $\begin{array}{l}\text { Single- and two-stage } \\
\text { diluted-sulfuric acid } \\
\text { pretreatment }\end{array}$ & Degraded dissolved sugars & [106] \\
\hline Corn stalks & $\begin{array}{l}\text { Autohydrolysis and alkaline } \\
\text { extraction processes }\end{array}$ & Hemicellulose of high purity & [107] \\
\hline Biomass & $\begin{array}{l}\text { Hot water treatment and } \\
\text { water/acetone extraction }\end{array}$ & $\begin{array}{l}\text { Cleavage of hemicellulose } \\
\text { acetate groups }\end{array}$ & [108] \\
\hline Spruce & $\begin{array}{c}\text { Microwave oven or steam } \\
\text { treatment }\end{array}$ & $\begin{array}{c}\text { Successful extracion of } \\
\text { hemicellulosic } \\
\text { oligosaccharides }\end{array}$ & [109] \\
\hline Kraft pulp & $\begin{array}{l}\text { Extraction with ionic } \\
\text { liquid/cosolvent systems }\end{array}$ & $\begin{array}{l}\text { Hemicellulose with high } \\
\text { purity }\end{array}$ & [110] \\
\hline
\end{tabular}

Firstly, hemicelluloses have been used as fermentation feedstocks in production of ethanol, butanol, and xylitol [111] [113] and as raw materials in the preparation of food packaging films [114] [115].

Secondly, due to their large content of hydroxyl groups, hemicelluloses can be modified by both chemical reactions and physical interactions. The main chemical reactions are etherification, esterification and chemical crosslinking which allow preparing many materials such as packing films, oxygen barrier [114] and water-resistant coatings [115] [116].

Nevertheless, most of the materials made with hemicelluloses are smart hydrogels. Many kinds of hemicelluloses from different of plants such as birch 
wood, aspen wood, spruce, bamboo, straw etc., have been used for the preparation of such materials. However, these hydrogels display weak thermostability, brittle properties and weak mechanical properties which restrict their application in material field. Nevertheless, this can be partially overcome through blending hemicelluloses with compatible products, as shown in Table 7.

\section{Chitin and Chitosan-Based Smart Materials}

Chitin is the most widespread aminopolysaccharide and is the second natural polysaccharide after cellulose that can be obtained as a cheap renewable biopolymer from marine sources. As shown in Figure 9, chitin is a poly- $\beta$-1,4- $N$-acetylglucosamine. It is found in arthropod exoskeletons, tendons, and the linings of their respiratory, excretory, and digestive systems and in the cell wall of fungi.

Due to its intermolecular hydrogen bonds, chitin is insoluble in water and in organic solvents, which, despite its enormous availability, limits its use. Nevertheless, several attempts have been reported to solve this problem owing to chemical modifications which allowed giving rise to derivatives such as chitosan or carboxymethyl chitin. Indeed, most of those derivatives are soluble in aqueous media and can be used as fibers, hydrogels, beads, sponges, and membranes [133].

The main applications of chitin and chitosan materials have been thoroughly reviewed by some researchers [133] [134].

Nevertheless, chitin-based smart materials or composites have also been created. Among those materials, shape memory materials containing polyurethanes molecules, are gaining more attention. Indeed, polyurethanes present good shape memory effect at room temperature. But polyurethanes cannot bear repeated changes in the shape memory, and retention will decrease by increasing the number of cycles of shape memory. Consequently, chitin-based polyurethane shape memory materials have been developed to overcome those problems [135] [136].

Chitosan is a linear polysaccharide composed by two kinds of randomly distributed $\beta(1 \rightarrow 4)$-linked structural units: 2-amino-2-deoxy-d-glucopyranose (D-glucosamine) and 2-acetamid-2-deoxy-d-glucopyranose ( $\mathrm{N}$-acetyl- $D$ glucosamine). It is obtained by extensive deacetylation of chitin.

Considering its low toxicity, biocompatibility, biodegradability and indirect abundance in nature, chitosan has attracted much research interest and has found potential applications in pharmaceutical, paper, textiles, cosmetic, and food industries, as well as in agriculture and medicine [137] [138].

Moreover, chitosan is known for its absorption of exudes, anti-fungal, anti-microbial, anti-viral and wound-healing properties and is useful as a wound management aid to reduce scar tissue.

There is an increased interest in preparing chitosan and various macromolecules blends for mitigating undesirable properties and a rapidly growing list of 
Table 7. Hemicellulose-based hydrogels: origine, properties and potential applications.

\begin{tabular}{|c|c|c|c|c|}
\hline Raw material & Hemicellulose & Hydrogel synthesis & $\begin{array}{l}\text { Hydrogel properties and } \\
\text { potential applications }\end{array}$ & Reference \\
\hline Bambo & Xylan & Grafting with AA + Crosslinking & High swelling, sensitive to $\mathrm{pH}$ & [117] \\
\hline Spruce pulp & AcGGM & Grafting with MA + Crosslinking & Drug release & [118] \\
\hline $\begin{array}{l}\text { Crude spruce } \\
\text { hydrolysate }\end{array}$ & AcGGM & $\begin{array}{c}\text { Free radical graft copolymerization and } \\
\text { cross-linking of } \\
\text { poly(amidoamine)/AcGGM }\end{array}$ & $\begin{array}{l}\text { High absorption capacity } \\
\text { for heavy metal ions }\end{array}$ & [119] \\
\hline Dextran & AcGGM & $\begin{array}{l}\text { In situ Michael-type addition } \\
\text { using vinyl sulfone }\end{array}$ & $\begin{array}{l}\text { Thermosensitive } \\
\text { injectable hydrogels }\end{array}$ & [120] \\
\hline Birch wood & Xylan & $\begin{array}{c}\text { Introduction of allyl groups }+ \text { reaction } \\
\text { with thioacetic acid, + free thiol-thiol } \\
\text { oxidative coupling }\end{array}$ & $\begin{array}{l}\text { 3D hydrogel scaffolds and } \\
\text { cross-linked foams }\end{array}$ & [121] \\
\hline $\begin{array}{l}\text { Crude spruce } \\
\text { hydrolysate }\end{array}$ & AcGGM & $\begin{array}{l}\text { Direct incorporation of hemicellulose } \\
\text { into a semi-IPN matrix obtained by } \\
\text { crosslinking polymerization } \\
\text { of MA-CMC with AA }\end{array}$ & $\begin{array}{l}\text { Appreciable mechanical } \\
\text { performance and high } \\
\text { swelling ratio }\end{array}$ & [122] \\
\hline $\begin{array}{l}\text { Crude spruce } \\
\text { hydrolysate }\end{array}$ & AcGGM & $\begin{array}{l}\text { Synthesis of Hemicellulose full IPN by } \\
\text { free-radical polymerization } \\
\text { and a thiol-ene click reaction }\end{array}$ & $\begin{array}{l}\text { Fast swelling rates and } \\
\text { highly porous structure }\end{array}$ & [123] \\
\hline Spruce TMP & AcGGM & $\begin{array}{l}\text { Functionalization of carboxylated AcGGM } \\
\text { with GMA and covalent immobilization } \\
\text { of conductive AT onto GMA. }\end{array}$ & $\begin{array}{l}\text { Electrically conductive } \\
\text { hydrogels with high and } \\
\text { controllable swelling }\end{array}$ & [124] \\
\hline Spruce TMP & AcGGM & $\begin{array}{l}\text { Cross-linking of AcGGM in a One-pot } \\
\text { reaction with } \mathrm{E} \text { in the presence of AP }\end{array}$ & $\begin{array}{l}\text { Conductivity, swelling and } \\
\text { mechanical properties for } \\
\text { biomedical applications }\end{array}$ & [125] \\
\hline Spruce TMP & AcGGM & $\begin{array}{l}\text { In situ fabrication of microgels by } \\
\text { chemical cross-linking during spray drying }\end{array}$ & $\begin{array}{l}\text { Conductivity, } \\
\text { mechanical properties, } \\
\text { biomedical applications }\end{array}$ & [126] \\
\hline $\begin{array}{c}\text { Eucalyptus } \\
\text { (Acid acetic pulping) }\end{array}$ & $\begin{array}{l}\text { Xylan and } \\
\text { glucomannan }\end{array}$ & $\begin{array}{l}\text { Grafting maleic MA to hemicellulose and } \\
\text { UV photo-crosslinking with NIPAAm }\end{array}$ & Temperature responsive & [127] \\
\hline Birchwood & $\begin{array}{l}\text { Xylan with } \\
\text { glucuronic acid } \\
\text { functionalities }\end{array}$ & $\begin{array}{l}\text { Network formation by complexation } \\
\text { between glucuronic acid of xylan and } \\
\text { amino groups of chitosan }\end{array}$ & Porous structure, sensitive to $\mathrm{pH}$. & [128] \\
\hline Bamboo & $\begin{array}{l}\text { Xylan with glucuronic } \\
\text { acid functionalities }\end{array}$ & $\begin{array}{l}\text { Use of Freeze-thaw process to obtain } \\
\text { reinforced hybrid hydrogel of } \\
\text { Hemicelluloses/PVA/Chitin Nanowhiskers }\end{array}$ & $\begin{array}{l}\text { Improved mechanical and } \\
\text { thermal properties (applications } \\
\text { in tissue engineering) }\end{array}$ & $\begin{array}{l}{[129]} \\
{[130]}\end{array}$ \\
\hline Beech & Xylan & $\begin{array}{c}\text { Mixing of Xylan, } \\
\text { kappa-carrageenan and oat spelt }\end{array}$ & $\begin{array}{l}\text { Improvement of gelling and } \\
\text { melting temperatures of } \\
\text { Kappa-Carrageenan hydrogels }\end{array}$ & [131] \\
\hline $\begin{array}{l}\text { Pinewood, } \\
\text { Switchgras and Coastal } \\
\text { bermuda grass }\end{array}$ & $\begin{array}{c}\text { Various } \\
\text { hemicelluloses }\end{array}$ & $\begin{array}{l}\text { Grafting with DTPA and } \\
\text { cross-linking with chitosan }\end{array}$ & $\begin{array}{l}\text { Biosorbent for Water Desalination } \\
\text { and Heavy Metal Removal }\end{array}$ & [132] \\
\hline
\end{tabular}

Abreviations: AA: Acrylic acid; MA: Maleic anhydride; AcGGM: $O$ acetyl-galactoglucomannan; AP: Aniline pentamer; AT: Aniline tetramer; DTPA: Diethylene triamime pentacetic acid; E: Epichlorohydrine; GMA: Glycidyl methacrylate; IPN: interpenetrating polymer network; MA-CMC: Methacrylated Carboxymethylcellulose; NIPAAm: N-isopropylacrylamide; TMP: Thermo-mechanical pulping. 


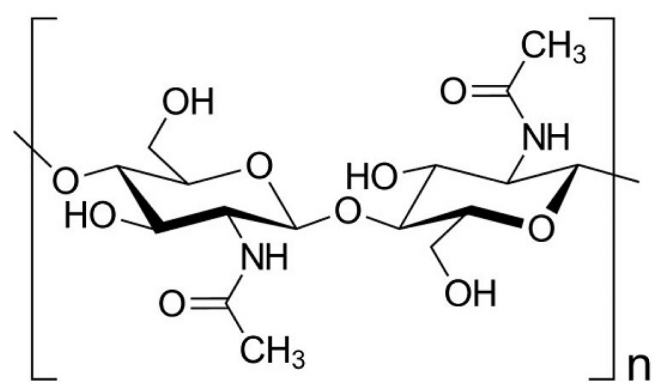

Figure 9. Chemical structure of chitin.

biomaterial applications. Examples are chitosan blends with cellulose, cellulose acetate, xanthan, gelatin, silk, polyamide, poly (acrylic acid), poly (vinyl alcohol), polyamide, gellan, collagen, glycine, poly ( $\mathrm{N}$-vinyl pyrrolidone).

On the other hand, chitosan structure can be modified through its amino group and the hydroxyl groups. These chemical modifications improve chitosan mechanical properties and solubility or bring new functional properties and promising applications. In this sense, a wide variety of chitosan thermosensitive materials has been generated, like nanostructures, scaffolds, membranes, cryogels and paramagnetic beads, to cite some of them [139].

Moreover, because of the polyelectrolyte nature of chitosan, several chitosan-based materials are also sensitive to changes of $\mathrm{pH}$, ionic strength etc, and hence have an advanced interest due to specific technological potential applications as sensors, actuators, controllable membrane for separations and modulators of drugs delivery for use in medicine, biotechnology and other fields.

On the other hand, chitosan can also be induced to undergo reversible sol-gel transition forming hydrogels or films by changing chemical or $\mathrm{pH}$ gradients [140]. These materials offer a versatile platform and customizable functionality to interface and interact with labile biologics (biomolecules, proteins, enzymes, cells) in aqueous environment. They are widely used in composite film coating, tissue engineering and drug delivery for creating functional materials with desired physical, chemical properties and even biological functionalities (Table 8).

\section{Alginate-Based Smart Materials}

Alginate is a natural polysaccharide that has two main sources: bacteria and seaweed (brown algae). It is composed of mannuronic acid residues (M-blocks), guluronic acid residues (G-blocks) and alternating $M$ and $G$ residues (MG-blocks). This chemical composition shows that alginate is a polymer with a polyelectrolyte nature.

Alginate, exhibits excellent biocompatibility and biodegradability and has many different industrial applications linked to 1) its ability to absorb water 2) its gelling, viscosifying and stabilizing properties. Alginate is used in several industrial fields such as textiles, food, pharmaceuticals, cosmetics, waste water treatment and paper industry together with biomedical supplies.

Alginate is readily processable for applicable three-dimensional scaffolding 
Table 8. Chitosan-based stimuli-responsive hydrogels: functionalization, synthesis, properties and applications.

\begin{tabular}{|c|c|c|c|c|}
\hline Functionalization & Synthesis & Characteristic & Application & Reference \\
\hline Cross-linking & $\begin{array}{l}\text { With glutaraldehyde } \\
\text { and sulfosuccinic acid }\end{array}$ & Protonic conductivity & Membrans for Fuel cells & [141] \\
\hline Cross-linking & With di- and tri-carboxylic acids & nano-hydrogels & Drug release & [142] [143] \\
\hline $\begin{array}{c}\text { Graft } \\
\text { copolymerization }\end{array}$ & $\begin{array}{l}\text { Copolymerization of metacrylic } \\
\text { acid with chitosan in the presence } \\
\text { of APS }\end{array}$ & Improved water solubility & Antibacterial activity & [144] \\
\hline $\begin{array}{c}\text { Graft } \\
\text { copolymerization }\end{array}$ & $\begin{array}{l}\text { Copolymerization of maleic acid } \\
\text { with (CMCTS) and (HPCTS) }\end{array}$ & Improved scavenging ability & Antioxidant activity & [145] \\
\hline $\begin{array}{c}\text { Graft } \\
\text { copolymerization }\end{array}$ & $\begin{array}{l}\text { Copolymerization of } \\
\text { aniline with chitosan }\end{array}$ & Protonic conductivity & Conductive films and fibers & [146] \\
\hline Carboxymethylation & Monochloroaetic acid & Solubility depends on $\mathrm{pH}$ & $\begin{array}{l}\text { Antimicrobial activity, } \\
\text { affinity with metal ions, } \\
\text { Controlled release of drugs }\end{array}$ & [147] \\
\hline Phosphorylation & $\begin{array}{l}\text { Heating chitosan with } \\
\text { orthophosphoric acid in DMF or } \\
\text { with phosphorous pentoxide in } \\
\text { methanesulphonic acid }\end{array}$ & $\begin{array}{l}\text { Solubility in water under } \\
\text { neutral conditions }\end{array}$ & $\begin{array}{l}\text { Bactericidal, biocompatible, } \\
\text { bioabsorbable, osteoinductive } \\
\text { and metal chelating properties }\end{array}$ & [148] \\
\hline Esterification & $\begin{array}{l}\text { Reaction of acyl chlorides with } \\
\text { chitosan (synthesis of } N, O \text {-Acyl } \\
\text { chitosan derivatives) }\end{array}$ & $\begin{array}{l}\text { Reaction mainly occurred } \\
\text { on the } \mathrm{OH} \text { group and } \\
\text { not on the } \mathrm{NH}_{2} \text { group }\end{array}$ & $\begin{array}{l}\text { Highly improved } \\
\text { antifungal activity }\end{array}$ & [149] \\
\hline Etherification & $\begin{array}{l}\text { Synthesis of } N \text {-phthaloyl } \\
\text { chitosan. (MPEG) iodide }\end{array}$ & $\begin{array}{l}\text { Soluble in water and aqueous } \\
\text { solutions of wide } \mathrm{pH} \text { range }\end{array}$ & $\begin{array}{c}\text { Extremely low reduced } \\
\text { viscosity }\end{array}$ & [150] \\
\hline $\begin{array}{l}\text { Self-rearrangement of } \\
\text { polymer networks }\end{array}$ & $\begin{array}{l}\text { chitosan/chondroitin sulfate } \\
\text { formed by polyelectrolyte } \\
\text { complexation }\end{array}$ & $\begin{array}{l}\text { Crystallinity, higher thermal } \\
\text { stability, porosity, and water } \\
\text { uptake capacity }\end{array}$ & $\begin{array}{c}\text { pH sensitive material which can } \\
\text { be tailored to several specific } \\
\text { applications }\end{array}$ & {$[151][152]$} \\
\hline $\begin{array}{l}\mathrm{BC} / \mathrm{Ch} \text { composite } \\
\text { preparation }\end{array}$ & $\begin{array}{l}\text { Immersing wet } \mathrm{BC} \text { pellicle in } \\
\text { chitosan solution followed by } \\
\text { freeze-drying }\end{array}$ & $\begin{array}{l}\text { porous network structure } \\
\text { and large aspect surface }\end{array}$ & $\begin{array}{l}\text { Wound dressing or } \\
\text { tissue-engineering scaffolds }\end{array}$ & [153] \\
\hline Reversible blending & Mixing of chitosan/PHEMA & Swollen structure & Electrically sensitive behavior & [154] \\
\hline $\begin{array}{l}\text { Electrospun } \\
\text { chitosan fibers }\end{array}$ & $\begin{array}{l}\text { Electro-wet-spinning } \\
\text { (submicron scale) }\end{array}$ & $\begin{array}{l}\text { Fast and reversible } \\
\text { electroactuation }\end{array}$ & $\begin{array}{c}\text { Application in artificial } \\
\text { muscles }\end{array}$ & [155] \\
\hline \multirow[t]{2}{*}{$\begin{array}{l}\text { Blending of chitosan } \\
\text { and Cellulose }\end{array}$} & $\begin{array}{c}\text { Preparation of } \\
\text { chitosan/cellulose blend beads }\end{array}$ & $\begin{array}{l}\text { Blend beads with rough and } \\
\text { folded surface morphology }\end{array}$ & $\begin{array}{l}\text { Odor treatment and metal ions } \\
\text { adsorption }\end{array}$ & [156] \\
\hline & $\begin{array}{l}\text { Casting of a TFA solution of } \\
\text { chitosan and cellulose }\end{array}$ & $\begin{array}{l}\text { Large bending displacement } \\
\text { under low voltage }\end{array}$ & $\begin{array}{l}\text { Blended dry and } \\
\text { durable actuator }\end{array}$ & [157] \\
\hline $\begin{array}{c}\text { Blending of chitosan } \\
\text { with PCL }\end{array}$ & $\begin{array}{l}\text { Chitosan and PCL } \\
\text { homogeneously dissolved in } \\
\text { acetic acid/water and processed } \\
\text { into uniform membranes }\end{array}$ & Blends with chemical bonds & $\begin{array}{l}\text { biological and anti-bacterial } \\
\text { properties }\end{array}$ & [158] \\
\hline $\begin{array}{l}\text { Preparation of } \\
\text { poly }(\mathrm{AA}-\mathrm{co} \\
\mathrm{AM}) /(\mathrm{O}-\mathrm{CMC}) \\
\text { interpenetrating } \\
\text { polymer network }\end{array}$ & $\begin{array}{l}\text { Synthesis of a semi-IPN by AA } \\
\text { and AM copolymerization of in } \\
\text { the presence of O-CMCthen } \\
\text { synthesis of a full-IPN } \\
\text { through cross-linking }\end{array}$ & Superporous hydrogel & $\begin{array}{l}\text { Mucosal drug delivery system, } \\
\text { especially for peroral delivery of } \\
\text { peptide and protein drugs }\end{array}$ & [159] \\
\hline
\end{tabular}

Abreviations: APS: Ammonium persulfate; BC: Bacterial cellulose; Ch: Chitosan; CMCTS: chitosan-carboxymethyl chitosan; DMF: N,N-dimethylformamide; HPCTS: hydroxypropyl chitosan; IPN: Interpenetrated Network; MPEG: Poly (ethylene glycol) monomethyl ether; NMMO: $N$-Methylmorpholine- $N$-oxide; PCL: poly ( $\varepsilon$-caprolactone); PHEMA: poly (hydroxyethyl methacrylate); TFA: Trifluoroacetic acid; AA: Acrylic acid; AM: Acrylamid; OCMC: O-carboxymethyl chitosan. 
materials such as hydrogels, microspheres, microcapsules, sponges, foams and fibers that provide responses to internal/external stimuli.

Alginate-based biomaterials can be utilized as drug delivery systems and cell carriers for tissue engineering, control release, matrix for living cells, immobilization of microorganisms [160]. Recently, there is a growing research interest in the applications and development of novel sustainable hydrogel materials for waste water treatment [161], and as an alternative to smart electrolytic gels for rapid electroencephalography monitoring and easy cleaning procedures [162].

As cellulose, hemicelluloses and chitosan, alginate can be easily modified via chemical reactions and physical interactions, to obtain derivatives with various structures, properties, functions and applications. Various techniques such as 1) oxidation, sulfation, copolymerization and coupling of cyclodextrin units, 2) esterification, use of Ugi reaction and amidation, are employed for chemical modification of the hydroxyl groups and carboxyl groups of alginate, respectively [163].

Moreover, owing to its structure and properties, alginate can be achieved through 1) combination with other biomaterials, 2) immobilization of specific ligands such as peptide and sugar molecules, and 3) physical or chemical crosslinking (Table 9).

\section{Conclusion and Perspectives}

This paper reviews the recent progress developed to produce and characterize smart materials using the most abundant products of the biomass, i.e. polysaccharides which include cellulose, hemicelluloses, chitin, chitosan, and alginates and their by-products. Owing to their low density, thermal stability, chemical resistance, high mechanical strength, biocompatibility, biodegradability, functionality, durability and uniformity, those products are materials of choice for the preparation of smart products that can be used in the very promising areas of nanotechnology, foods, cosmetics and medicine (mainly controlled drug release and regenerative medicine) and so, opening up major commercial markets in the context of green chemistry.

The resulting smart materials are generally prepared through direct utilization and/or after chemical or physical modifications of the polysaccharides.

Cellulose and its different physical structures (particularly cellulose nanofibers and nanoparticles, i.e. nanocelluloses) can be transformed into high value-added smart blends and composites with applications in important industrial areas such as those of flexible circuits, solar panels, implant materials, cartilage tissue engineering, drug delivery, etc.

Moreover, owing to its unique cristalline structure and its piezoelectric behaviour, cellulose has also the characteristics of an electroactive polymer, with potential applications in biomimetic sensors/actuators and electromechanical biosystems.

Together with hemicelluloses, chitosans and alginates, cellulose can give rise 
Table 9. Main smart alginate derivatives obtained by functionalization processes.

\begin{tabular}{|c|c|c|c|c|}
\hline Functionalization & Experimental strategy & Material characteristics & Application & Reference \\
\hline Oxidation & $\begin{array}{l}\text { Controlled reactions on-OH } \\
\text { groups of } \mathrm{C}-2 \text { and } \\
\mathrm{C}-3 \text { with sodium periodate }\end{array}$ & $\begin{array}{l}\text { Cleavage of carbon-carbon } \\
\text { bond of cis-diol groups and } \\
\text { formation of acetal groups }\end{array}$ & $\begin{array}{l}\text { Powerful material for } \\
\text { tissue engineering, } \\
\text { Drug-controlled } \\
\text { delivery systems }\end{array}$ & {$[164][165]$} \\
\hline Sulfation & $\begin{array}{l}\text { Reaction of sodium alginate } \\
\text { with a sulfating agent } \\
\qquad\left(\mathrm{N}\left(\mathrm{SO}_{3} \mathrm{Na}\right)_{3}\right)\end{array}$ & $\begin{array}{l}\text { Sodium alginate sulfate } \\
\text { with DS of } 1.87\end{array}$ & Anticoagulant activity & {$[166]$} \\
\hline \multirow{3}{*}{$\begin{array}{l}\text { Reductive-amination of } \\
\text { oxidized alginate }\end{array}$} & $\begin{array}{l}\text { Reaction with } \mathrm{ClSO}_{3} \mathrm{H} \text { in } \\
\text { formamide }\end{array}$ & $\begin{array}{l}\text { Alginate sulfate and its } \\
\text { quaterized derivatives }\end{array}$ & $\begin{array}{c}\text { Anticoagulant activity and } \\
\text { potential application as } \\
\text { anti-HIV }\end{array}$ & [167] \\
\hline & $\begin{array}{l}\text { Synthesis of APSs with a linear } \\
\text { alkyl group }(\mathrm{C} 8, \mathrm{C} 12, \mathrm{C} 16)\end{array}$ & Low interfacial tension value & $\begin{array}{l}\text { Surfactant activity and } \\
\text { adsorption of heavy metal }\end{array}$ & {$[168]$} \\
\hline & $\begin{array}{l}\text { Syntheseis of (HM-alginate) } \\
\text { via reaction of sodium alginate } \\
\text { with dodecyl glycidyl ether }\end{array}$ & $\begin{array}{l}\text { Zeta-potential of HM-alginate } \\
\text { higher than that of sodium } \\
\text { alginate. Very low viscosity }\end{array}$ & $\begin{array}{c}\text { Ecology-safe material to } \\
\text { encapsulate lipophilic } \\
\text { substances }\end{array}$ & [169] \\
\hline \multirow[t]{3}{*}{ Copolymerization } & $\begin{array}{l}\text { Synthesis of a copolymer } \\
\text { of sodium acrylate } \\
\text { with sodium alginate }\end{array}$ & $\begin{array}{l}\text { Water absorbency of the } \\
\text { hydrogel } \geq 85 \text { times } \\
\text { its own mass }\end{array}$ & $\begin{array}{l}\text { Superabsorbent resistant } \\
\text { to salinesolution }\end{array}$ & {$[170]$} \\
\hline & $\begin{array}{l}\text { Microwave-initiated } \\
\text { synthesis of } \\
\text { SA-g-PAM }\end{array}$ & $\begin{array}{l}\mathrm{M}_{\mathrm{W}} \text { and Intrinsic viscosity } \\
\text { greater than that of SAG. }\end{array}$ & Polymeric flocculant & {$[171]$} \\
\hline & $\begin{array}{c}\text { Graft copolymerization of VSA } \\
\text { onto alginate in the presence } \\
\text { of (PDP)/thiourea }\end{array}$ & $\begin{array}{l}\text { Thermally more stable than } \\
\text { alginate }\end{array}$ & $\begin{array}{l}\text { Metal ion sorption, } \\
\text { Flocculant, Resistant to } \\
\text { biodegradability }\end{array}$ & [172] \\
\hline \multirow[t]{2}{*}{ Esterification } & $\begin{array}{l}\text { Synthesis of derivatives of } \\
\text { sodium alginate, by chemical } \\
\text { binding of long alkyl chains } \\
\text { onto alginate backbone via } \\
\text { ester functions }\end{array}$ & $\begin{array}{l}\text { Increasing of the hydrophobic } \\
\text { nature of native alginate }\end{array}$ & $\begin{array}{c}\text { Protein carrier with } \\
\text { High encapsulation yields } \\
\text { and important release } \\
\text { properties }\end{array}$ & [173] \\
\hline & $\begin{array}{l}\text { Esterification of alginate by } \\
\text { butanol }\end{array}$ & $\begin{array}{l}\text { Very stable material with } \\
\text { gelling and non-toxic } \\
\text { properties }\end{array}$ & $\begin{array}{l}\text { Encapsulation of both } \\
\text { hydrophilic and } \\
\text { hydrophobic molecules }\end{array}$ & [174] \\
\hline Ugi reaction & $\begin{array}{l}\text { Sodium alginate dissolved in } \\
\text { water + formaldehyde, } \\
\text { octylamine and } \\
\text { cyclohexyl isocyanide }\end{array}$ & $\begin{array}{l}\text { Self-aggregated micelles with } \\
\text { high thermal stability and } \\
\text { good amphiphilic functionality }\end{array}$ & $\begin{array}{l}\text { High potential in } \\
\text { pharmacology and } \\
\text { tissue engineering }\end{array}$ & [175] \\
\hline $\begin{array}{c}\text { Crosslinking } \\
\text { Preparation of poly (AA-co } \\
\text { AM)/(SA) interpenetrating } \\
\text { polymer network }\end{array}$ & $\begin{array}{l}\text { 1) Synthesis of a semi-IPN by } \\
\text { copolymerization } \\
\text { 2) Crosslinking with Bis }\end{array}$ & $\begin{array}{l}\text { IPN with a superporous } \\
\text { structure, good mechanical } \\
\text { properties, pH sensitivity }\end{array}$ & $\begin{array}{l}\text { Potential candidate } \\
\text { in the field of } \\
\text { Drug delivery system }\end{array}$ & {$[176]$} \\
\hline $\begin{array}{c}\text { Preparation of poly } \\
(\mathrm{AA}) /(\mathrm{SA}) \text { interpenetrating } \\
\text { polymer network }\end{array}$ & $\begin{array}{l}\text { 1) Synthesis of SA beads } \\
\text { 2) Synthesis of hydrogels } \\
\text { hybrids by polymerization of } \\
\text { AA and crosslinking }\end{array}$ & $\begin{array}{l}\text { Strong and elastic superporous } \\
\text { hydrogel, high network } \\
\text { density, good mechanical } \\
\text { properties }\end{array}$ & $\begin{array}{l}\text { Various pharmaceutical, } \\
\text { biomedical and industrial } \\
\text { applications }\end{array}$ & [177] \\
\hline
\end{tabular}

Abreviations: Bis: $N, N^{\prime}$-methylenebisacrylamide; DS: degree of substitution; APSs: alginate-derived polymeric surfactants; HM-alginate: hydrophobic modified alginate; $\mathrm{M}_{\mathrm{W}}$ : Weight average molecular weigth; SA: sodium alginate; SA-g-PAM: sodium alginate grafted polyacrylamide; VSA: vinyl sulfonic acid; PDP: potassium peroxydiphosphate. 
to several types of stimuli-responsive hydrogels (e.g. temperature responsive, $\mathrm{pH}$-sensitive, protonic conductor, etc.) able to be used in numerous applications such as tissue engineering, absorption of heavy metal ions, odor treatments, liquid and gas absorbtion, polymeric floculation, energy storage etc.

All those investigations clearly show the great potential of polysaccharides for the production of cheap, disposable and environmentally friendly devices. However, as shown in different sections of the present review, still more comprehensive studies are required to broaden the fundamental understanding of molecular level interactions that confer smartness to polysaccharides. This would allow manufacturing new materials with new applications, able to bring more technological impacts to markets.

Regarding innovation and bigger data: in a nutshell, the parallel between innovation and art has been progressively brought to the attention of the reader from a fairy tale landscape making innovative use of natural resources keeping "monuments in place". Followed by the foreseeing, "4C", dimension of the collaborative skills developed back in 1998 by Rebouillat [2], now extended to the Jazz science to education breadth [6] and its self-learning integration value, associated with a high degree of intrinsic improvision serving innovation, the loop on the innovation subject matter, in the present work, is closed with the bigger data and artificial intelligence, and, its emotional intelligence limitations and potential for misleadingness that may deserve a longer propos in a review to come.

Finally, Smart Materials are along with Innovation attributes and Artificial Intelligence among the most used "buzz" words in all media. Central to their practical occurrence, many talents are to be gathered within new contextual data influxes. Has this, in the last 20 years, changed some of the essential fundamental dimensions and the required skills of the actors such as providers, users, insiders, etc.? This is a preliminary focus and prelude of this review which shall not be ignored.

The era of smart materials may deserve an artistic warning-illustration to complete the picture of its tremendous potential with some level of disruptive improvisation in Figure 10.

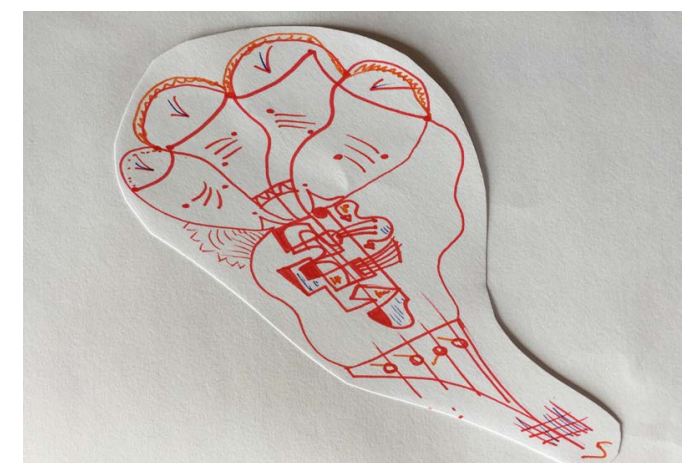

Figure 10. "The hand-footed, to travel a New Universe." Private art to illustrate smart technologies approaches on smart gloves and augmented natural abilities, (c) Letibarlou, 2018. 


\section{Acknowledgements}

Benoit Steffenino: DuPont ${ }^{\text {Tw }}$ Fellow technologist. His pictorial skills bring concepts to an entertaining journey.

\section{Conflicts of Interest}

The authors declare no conflicts of interest regarding the publication of this paper.

\section{More about the Authors}

Serge Rebouillat [Phonetically: Rebooya], Dr. Ing., Docteur ès Sciences, Certified Prof., Ind. Energetic, Chem/Bio Eng., Rheology, IP: Mediation/Innovation \& Strategy/Management/Valuation.

Fernand Pla, Dr. Ing., Dr-es-Sciences Physiques, full Professor at the University of Lorraine (Nancy, France), Head of a research group working in Polymer Reaction Engineering.

\section{Disclaimer}

This article is primarily for educational purposes. Selected cases are strictly illustrative. Neither the authors nor the illustrator assume any liability for any errors or oversights, for how this article or its contents are utilized or interpreted or for any consequences resulting directly or indirectly from the usage of it.

This information is for general knowledge. For critical applications, requirements should be checked with the suppliers. For additional guidance, legal or any other, seek advice from the appropriate qualified professionals; this study can by no means substitute for legal, technical and managerial expert advice.

The opinions expressed by the writers in this article do not necessarily represent the viewpoints of the company which one of the authors is employed by.

\section{References}

[1] Rebouillat, S. and Noirhomme, B. (2018) Open-Innovation in the Electrical and Electronic Industries: Engineered Bio-Fluid Compositions Are Paving the Way, and Testing Therewith. Journal of Biomaterials and Nanobiotechnology, 9, 189-209. https://doi.org/10.4236/jbnb.2018.92011

[2] Rebouillat, S. (1998) Foresee Concept and Young Chemists Industrial Training. The “4C" Skill Balance and the "Intrapreneur". L'Actualité Chimique, 214, 23-24. https://www.lactualitechimique.org/numero/425

[3] Lapray, D. and Rebouillat, S. (2014) "Bigger Data" Visualization to Visual Analytics: A Path to Innovation. "Happening, Definitely! Misleading, Possibly?" A Review of Some Examples Applicable to IP Discovery. International Journal of Innovation and Applied Studies, 7, 1251-1273. http://www.ijias.issr-journals.org/

[4] Lapray, M. and Rebouillat, S. (2014) Innovation Review: Closed, Open, Collaborative, Disruptive, Inclusive, Nested... and Soon Reverse. How about the Metrics: Dream and Reality. International Journal of Innovation and Applied Studies, 9, 1-28. http://www.ijias.issr-journals.org/

[5] Rebouillat, S., Lyons, M.E.G., Doyle, B.M.P. and Richard, L. (2011) Paving the Way 
to the Integration of Smart Nanostructures: Part II: Nanostructured Microdispersed Hydrated Metal Oxides for Electrochemical Energy Conversion and Storage Applications. International Journal of Electrochemical Science, 6, 5830-5917.

[6] Calamel, C. (2010) Le jazz comme science d'éducation: Vers un modèle explicatif du jazz à partir de la formation des savoirs du jazzman. PhD Thesis, University of Paris 10, France.

[7] Rebouillat, S. (2016) Aramids: "Disruptive", Open and Continuous Innovation. In: Chen, X., Ed., Advanced Fibrous Composite Materials for Ballistic Protection, Woodhead Publishing Ltd., Sawston, 11.

[8] Rebouillat, S. (1998) Carbon Fiber Applications in Carbon Fibers. 3rd Edition, Edited, Revised and Expanded by Donnet, J.-B., Wang, T.K., Rebouillat, S. and Peng, J.C.M., CRC Press, Marcel Dekker, New-York, 573.

[9] Lapray, M. and Rebouillat, S. (2016) A Science \& Business Equation for "Bio-Inspired" Innovation. The 3rd International Conference on Bioinspired and Biobased Chemistry \& Materials, Nice, 16-19 October 2016.

[10] Rebouillat, S. (2013) A Science and Business Equation for Collaborative Corporate Innovation. Business Strategy, IP Strategy, R\&D Strategy: An All-in-One Business Model. A Review with a Bio-Technology and Green Chemistry Focus. International Journal of Innovation and Applied Studies, 4, 1-19.

http://www.ijias.issr-journals.org/

[11] Rebouillat, S. and Lapray, D. (2014) A Review Assessing the "Used in the Art" Intellectual Property Search Methods and the Innovation Impact Therewith. International Journal of Innovation and Applied Studies, 5, 160-191.

http://www.ijias.issr-journals.org/

[12] Rebouillat, S. and Lapray, M. (2014) Bio-Inspired and Bio-Inspiration: A Disruptive Innovation Opportunity or a Matter of "Semantic"? A Review of a "Stronger than Logic" Creative Path Based on Curiosity and Confidence (4C22C). International Journal of Innovation and Applied Studies, 6, 299-325. http://www.ijias.issr-journals.org/

[13] Rebouillat, S. (2008) Grafted Para-Aramid Fiber and Method of Making. European Patent EP1123429.

[14] Rebouillat, S. and Pla, F. (2013) State of the Art Manufacturing and Engineering of Nanocellulose: A Review of Available Data and Industrial Applications. Journal of Biomaterials and Nanobiotechnology, 4, 165-188. https://doi.org/10.4236/jbnb.2013.42022

[15] Rebouillat, S. and Pla, F. (2016) Recent Strategies for the Development of Biosourced-Monomers, Oligomers and Polymer-based Materials: A Review with an Innovation and a Bigger Data Focus. Journal of Biomaterials and Nanobiotechnology, 7, 167-213. https://doi.org/10.4236/jbnb.2016.74017

[16] Ortega-Requena, S., Rebouillat, S. and Pla, F. (2018) Paving the High-Way to Sustainable, Value Adding Open-Innovation Integrating Bigger-Data Challenges: Three Examples from Bio-Ingredients to Robust Durable Applications of Electrochemical Impacts. Journal of Biomaterials and Nanobiotechnology, 9, 117-188. https://doi.org/10.4236/jbnb.2018.92010

[17] Spillman Jr., W.B., Sirkis, J.S. and Gardiner, P.T. (1996) Smart Materials and Structures: What Are They? Journal of Smart Materials and Structure, 5, 247-254.

[18] Rogers, C.A. (1993) Intelligent Material Systems-The Dawn of a New Materials Age. Journal of Intelligent Material Systems and Structures, 4, 4-12.

https://doi.org/10.1177/1045389X9300400102 
[19] Akhras, G. (1999) Advanced Composites for Smart Structures. Proceedings of the 12 th International Conference on Composite Materials, Paris, 5-9 July 1999.

[20] Cox, L.M., Killgore, J.P., Li, Z., Zhang, Z., Hurley, D.C., Xiao, J. and Ding, Y. (2014) Morphing Metal-Polymer Janus Particles. Advanced Materials, 26, 899-904.

[21] Ge, Q., Dunn, C.K., QI, H.J. and Dunn, M.L. (2014) Active Origami by 4D Printing. Journal of Smart Materials and Structure, 23, Article ID: 094007. https://doi.org/10.1088/0964-1726/23/9/094007

[22] Cox, L.M., Li, Z., Sowan, N., Nair, D., Xiao, J., Bowman, C.N. and Ding, Y. (2014) Reconfigurable Surface Patterns on Covalent Adaptive Network Polymers Using Nanoimprint Lithography. Polymer, 55, 5933-5937. https://doi.org/10.1016/j.polymer.2014.09.024

[23] Tadigadapa, S. and Mateti, K. (2009) Piezoelectric MEMS Sensors: State-of-the-Art and Perspectives. Measurement Science and Technology, 20, Article ID: 092001. https://doi.org/10.1088/0957-0233/20/9/092001

[24] Bogue, R. (2014) Smart Materials: A Review of Capabilities and Applications. Assembly Automation, 34, 16-22. https://doi.org/10.1108/AA-10-2013-094

[25] Fukada, E. (2000) History and Recent Progress in Piezoelectric Polymers. IEEE Transactions on Ultrasonics, Ferroelectrics, and Frequency Control, 47, 1277-1290. https://doi.org/10.1109/58.883516

[26] Quant, M., Elizalde, H., Flores, A., Ramírez, R., Orta, P. and Song, G. (2009) A Comprehensive Model for Piezoceramic Actuators: Modelling, Validation and Application. Smart Materials and Structures, 18, Article ID: 125011. https://doi.org/10.1088/0964-1726/18/12/125011

[27] Naresh, C., Bose, P. and Rao, C. (2016) IOP Conference Series: Materials Science and Engineering. In: Shape Memory Alloys: A State of Art Review, IOP Publishing, Bristol, UK, Article ID: 012054.

[28] Carpi, F., De Rossi, D., Kornbluh, R., Pelrine, R.E. and Sommer-Larsen, P. (2011) Dielectric Elastomers as Electromechanical Transducers: Fundamentals, Materials, Devices, Models and Applications of an Emerging Electroactive Polymer Technology. Elsevier, Amsterdam, The Netherlands.

[29] Choi, Y., Cho, J., Choi, S. and Wereley, N. (2005) Constitutive Models of Electrorheological and Magnetorheological Fluids Using Viscometers. Smart Materials and Structures, 14, 1025-1036. https://doi.org/10.1088/0964-1726/14/5/041

[30] Bar-Cohen, Y. (1996) EAP History, Current Status, and Infrastructure. In: Bar-Cohen, Y., Ed., Electroactive Polymer (EAP) Actuators as Artificial Muscles, SPIE Press, Bellingham, Washington DC, 3-42.

[31] Alvarez-Lorenzo, C., Blanco-Fernandez, B., Puga, A.M. and Concheiro, A. (2013) Crosslinked Ionic Polysaccharides for Stimuli-Sensitive Drug Delivery. Advanced Drug Delivery Reviews, 65, 1148-1171. https://doi.org/10.1016/j.addr.2013.04.016

[32] Thiele, J., Ma, Y.J., Bruekers, S.M.C., Ma, S.H. and Huck, W.T.S. (2014) Designer Hydrogels for Cell Cultures: A Materials Selection Guide. Advanced Materials, 26, 125-148. https://doi.org/10.1002/adma.201302958

[33] Lee, K.Y. and Mooney, D.J. (2012) Alginate: Properties and Biomedical Applications. Progress in Polymer Science, 37, 106-126. https://doi.org/10.1016/j.progpolymsci.2011.06.003

[34] Anwar, Z., Gulfraz, M. and Irshad, M. (2014) Agro-Industrial Lignocellulosic Biomass a Key to Unlock the Future Bio-Energy: A Brief Review. Journal of Radiation Research and Applied Sciences, 7, 163-173. 
https://doi.org/10.1016/j.jrras.2014.02.003

[35] Chen, H. (2014) Chemical Composition and Structure of Natural Lignocellulose. In: Chen, H.Z., Ed., Biotechnology of Lignocellulose: Theory and Practice, Springer, Netherlands, Dordrecht, 25-71. https://doi.org/10.1007/978-94-007-6898-7_2

[36] Tanase, E.E., Râpa, M. and Popa, O. (2014) Biopolymers Based on Renewable Resources-A Review. Scientific Bulletin Series F. Biotechnologies, 18, 188-195.

[37] Klem, D., Heublein, B., Fink, H. and Bohn, A. (2005) Cellulose: Fascinating Biopolymer and Sustainable Raw Material. Angewandte Chemie International Edition, 44, 3358-3393. https://doi.org/10.1002/anie.200460587

[38] Klemm, D., Philipp, B., Heinze, T., Heinze, U. and Wagenknecht, W. (1998) Comprehensive Cellulose Chemistry, Volume 1: Fundamentals and Analytical Methods. WILEY-VCH VerlagGmbH, Weinheim, Germany,

[39] Prabaharan, M. and Mano, J.F. (2006) Stimuli-Responsive Hydrogels Based on Polysaccharides Incorporated with Thermo-Responsive Polymers as Novel Biomaterials. Macromolecular Bioscience, 6, 991-1008. https://doi.org/10.1002/mabi.200600164

[40] Sannino, A., Demitri, C. and Madaghiele, M. (2009) Biodegradable Cellulose-Based Hydrogels: Design and Applications. Materials, 2, 353-373. https://doi.org/10.3390/ma2020353

[41] Prabaharan, M., Tiwari, A. and Li, S. (2010) Polysaccharides/Poly( $N$-Isopropylacrylamide)-Based Stimuli-Responsive Hydrogels as Novel Biomaterials. In: Li, S., Tiwari, A., Prabaharan, M. and Aryal, S., Eds., Smart Polymer Materials for Biomedical Applications, Nova Science Publishers, New York, 33-56.

[42] Zhang, Z., Chen, L., Zhao, C., Bai, Y., Deng, M., Shan, H., Zhuang, X., Chen, X. and Jing, X. (2011) Thermo- and pH-Responsive HPC-g-AA/AA Hydrogels for Controlled Drug Delivery Applications. Polymer, 52, 676-682.

https://doi.org/10.1016/j.polymer.2010.12.048

[43] Hubbe, M.A., Rojas, O.J., Lucia, L.A. and Sain, M. (2008) Cellulosic Nanocomposites: A Review. BioResources, 3, 929-980.

[44] Zhou, Y., Fuentes-Hernandez, C., Khan, T.M., Liu, J.C., Hsu, J., Shim, J.W., Dindar, A., Youngblood, J.P., Moon, R.J. and Kippelen, B. (2013) Recyclable Organic Solar Cells on Cellulose Nanocrystal Substrates. Scientific Reports, 3, Article No. 1536. https://doi.org/10.1038/srep01536

[45] Plaza, N., Zelinka, S.L., Stone, D.S. and Jakes, J.E. (2013) Plant-Based Torsional Actuator with Memory. Smart Materials and Structures, 22, Article ID: 072001.

[46] Qiu, X.Y. and Hu, S.W. (2013) "Smart” Materials Based on Cellulose: A Review of the Preparations, Properties, and Applications. Materials, 6, 738-781. https://doi.org/10.3390/ma6030738

[47] Nogi, M., Iwamoto, S. Nakagaito, A.N. and Yano, H. (2009) Optically Transparent Nanofiber Paper. Advanced Materials, 21, 1595-1598. https://doi.org/10.1002/adma.200803174

[48] Nogi, M. and Yano, H. (2008) Transparent Nanocomposites Based on Cellulose Produced by Bacteria Offer Potential Innovation in the Electronics Device Industry. Advanced Materials, 20, 1849-1852. https://doi.org/10.1002/adma.200702559

[49] Stigter, M., Bezemer, J., De Groot, K. and Layrolle, P. (2004) Incorporation of Different Antibiotics into Carbonated Hydroxyapatite Coatings on Titanium Implants, Release and Antibiotic Efficacy. Journal of Controlled Release, 99, 127-137. https://doi.org/10.1016/j.jconrel.2004.06.011 
[50] Müller, F.A., Müller, L., Hofmann, I., Greil, P., Wenzel, M.M. and Staudenmaier, R. (2006) Cellulose-Based Scaffold Materials for Cartilage Tissue Engineering. Biomaterials, 27, 3955-3963. https://doi.org/10.1016/j.biomaterials.2006.02.031

[51] Li, J., Wan, Y., Li, L., Liang, H. and Wang, J. (2009) Preparation and Characterization of 2,3-Dialdehyde Bacterial Cellulose for Potential Biodegradable Tissue Engineering Scaffolds. Materials Science and Engineering. C, 29, 1635-1642. https://doi.org/10.1016/j.msec.2009.01.006

[52] Giri, J. and Adhikari, R. (2012) A Brief Review on Extraction of Nanocellulose and Its Application. BIBECHANA, 9, 81-87. https://doi.org/10.3126/bibechana.v9i0.7179

[53] Jorfi, M. and Foster, E.J. (2015) Recent Advances in Nanocellulose for Biomedical Applications. Journal of Applied Polymer Science, 132, Article ID: 41719. https://doi.org/10.1002/app.41719

[54] Kim, J., Yun, S. and Ounaies, Z. (2006) Discovery of Cellulose as a Smart Material. Macromolecules, 39, 4202-4206. https://doi.org/10.1021/ma060261e

[55] Mohiuddin, M., Akther, A., Jo, E.B., Kim, H.C. and Kim, J. (2015) Fabrication and Finite Element Analysis of Vibrating Parallel Film Actuator Made with Cellulose Acetate for Potential Haptic Application. Proceedings of the Institution of $\mathrm{Me}$ chanical Engineers Part C: Journal of Mechanical Engineering Science, 230, 2720-2727.

[56] Kim, J., Song, C.S. and Yun, S.R. (2006) Cellulose Based Electro-Active Papers: Performance and Environmental Effects. Smart Materials and Structures, 15, 719-723. https://doi.org/10.1088/0964-1726/15/3/007

[57] Kim, J. and Seo, Y.B. (2002) Electro-Active Paper Actuators. Smart Materials and Structures, 11, 355-360. https://doi.org/10.1088/0964-1726/11/3/305

[58] Kim, J.H., Lee, S.W., Yun, G.Y., Yang, C., Kim, H.S. and Kim, J. (2009) Observation of Creep Behavior of Cellulose Electro-Active Paper (EAPap) Actuator. In: SPIE Smart Structures and Materials + Nondestructive Evaluation and Health Monitoring, Vol. 7289, Society of Photographic Instrumentation Engineers, Bellingham, 1-7. https://doi.org/10.1117/12.815565

[59] Kim, H.S., Kim, J., Jung, W., Ampofo, J., Craft, W. and Sankar, J. (2008) Mechanical Properties of Cellulose Electro-Active Paper under Different Environmental Conditions. Smart Materials and Structures, 17, Article ID: 015029. https://doi.org/10.1088/0964-1726/17/01/015029

[60] Shahinpoor, M. (2015) Ionic Polymer Metal Composites as Dexterous Manipulators and Haptic Feedback/Tactile Sensors for Minimally Invasive Robotic Surgery. In: Shahinpoor, M., Ed., Ionic Polymer Metal Composites (IPMCs): Smart Multi-Functional Materials and Artificial Muscles, Vol. 2, Royal Society of Chemistry, London, 311-340. https://doi.org/10.1039/9781782627234-00311

[61] Kim, J., Jung, W. and Kim, H.S. (2007) In-Plane Strain of Electro-Active Paper under Electric Fields. Sensors and Actuators A: Physical, 140, 225-231. https://doi.org/10.1016/j.sna.2007.06.041

[62] Saito, T., Kimura, S., Nishiyama, Y. and Isogai, A. (2007) Cellulose Nanofibers Prepared by TEMPO-Mediated Oxidation of Native Cellulose. Biomacromolecules, 8 , 2485-2491. https://doi.org/10.1021/bm0703970

[63] Kim, J., Zhai, L., Mun, S., Ko, H.-U. and Yun, Y.-M. (2015) Cellulose Nanocrystals, Nanofibers, and Their Composites as Renewable Smart Materials. In: The 22nd International Symposium on Smart Structures and Materials \& Nondestructive Evaluation and Health Monitoring, Vol. 9434, International Society for Optics and 
Photonics, Bellingham, WA, 1-6.

[64] Mahadeva, S.K., Yun, S. and Kim, J. (2009) Dry Electroactive Paper Actuator Based on Cellulose/Poly(Ethylene Oxide) - Poly(Ethylene Glycol) Microcomposite. Journal of Intelligent Material Systems and Structures, 20, 1141-1146. https://doi.org/10.1177/1045389X09103222

[65] Yang, S.Y. Mahadeva, S.K. and Kim, J. (2013) Remotely Powered and Controlled EAPap Actuator by Amplitude Modulated Microwaves. Smart Materials and Structures, 22, Article ID: 017001. https://doi.org/10.1088/0964-1726/22/1/017001

[66] Lee, S.W., Kim, J.H., Kim, J. and Kim, H.S. (2009) Characterization and Sensor Application of Celluloseelectro-Active Paper (EAPap). Chinese Science Bulletin, 54, 2703-2707.

[67] Kim, J., Lee, H. and Kim, H.S. (2010) Beam Vibration Control Using Cellulose-Based Electro-Active Paper Sensor. International Journal of Precision Engineering and Manufacturing, 11, 823-827. https://doi.org/10.1007/s12541-010-0099-8

[68] Yun, G.Y., Kim, J., Kim, J.H. and Kim, S.Y. (2010) Fabrication and Testing of Cellulose EAPap Actuators for Haptic Application. Sensors and Actuators A: Physical, 164, 68-73. https://doi.org/10.1016/j.sna.2010.09.005

[69] Kim, J., Yun, G.Y., Kim, J.H., Lee, J. and Kim, J.H. (2011) Piezoelectric Electro-Active Paper (EAPAP) Speaker. Journal of Mechanical Science and Technology, 25, 2763-2768. https://doi.org/10.1007/s12206-011-0718-Z

[70] Yun, S. and Kim, J. (2011) Mechanical, Electrical, Piezoelectric and Electro-Active Behavior of Aligned Multi-Walled Carbon Nanotube/Cellulose Composites. Carbon, 49, 518-527. https://doi.org/10.1016/j.carbon.2010.09.051

[71] King, A.G. (2007) Research Advances: DRPs: Let the Blood Flow; Smart Cellulose May Mean Paper Airplanes That Fly Like Butterflies; Converting Biomass Directly into Electricity. Journal of Chemical Education, 84, 10-14. https://doi.org/10.1021/ed084p10

[72] Silva, A.K.A., Richard, C., Bessodes, M., Scherman, D. and Merten, O.W. (2009) Growth Factor Delivery Approaches in Hydrogels. Biomacromolecules, 10, 9-18. https://doi.org/10.1021/bm801103c

[73] Bajpai, A.K., Shukla, S.K., Bhanu, S. and Kankane, S. (2008) Responsive Polymer in Controlled Drug Delivery. Progress in Polymer Science, 33, 1088-1118.

https://doi.org/10.1016/j.progpolymsci.2008.07.005

[74] Wu, D.Q., Wang, T., Lu, B., Xu, X.D., Cheng, S.X., Jiang, X.J., Zhang, X.Z. and Zhuo, R.X. (2008) Fabrication of Supramolecular Hydrogels for Drug Delivery and Stem Cell Encapsulation. Langmuir, 24, 10306-103012.

https://doi.org/10.1021/la8006876

[75] Khan, F., Tare, R., Richard, O., Oreffo, R. and Bradley, M. (2009) Versatile Biocompatible Polymer Hydrogels: Scaffolds for Cell Growth. Angewandate Chemie International Edition, 48, 978-982. https://doi.org/10.1002/anie.200804096

[76] Lee, K.Y. and Mooney, D.J. (2001) Hydrogel for Tissue Engineering. Chemical Reviews, 101, 1869-1880. https://doi.org/10.1021/cr000108x

[77] Lee, Y.J. and Braun, P.V. (2003) Tunable Inverse Opal Hydrogel pH Sensors. Advanced Materials, 15, 563-566. https://doi.org/10.1002/adma.200304588

[78] Sorber, J., Steiner, G., Schulz, V., Guenther, M., Gerlach, G., Salzer, R. and Amdt, K.F. (2008) Hydrogel-Based Piezoresistive pH Sensors: Investigations Using FT-IR Attenuated Total Reflection Spectroscopic Imaging. Analytical Chemistry, 80, 
2957-2962. https://doi.org/10.1021/ac702598n

[79] Katsoulos, C., Karageorgiadis, L., Vasileiou, N., Mousafeiropoulos, T. and Asimellis, G. (2009) Customized Hydrogel Contact Lenses for Keratoconus Incorporating Correction for Vertical Coma Aberration. Ophthalmic and Physiological Optics, 29, 321-329. https://doi.org/10.1111/j.1475-1313.2009.00645.x

[80] Yasuda, H. (2006) Biocompatibility of Nanofilm-Encapsulated Silicone-Hydrogel Contact Lenses. Macromolecular Bioscience, 6, 121-138. https://doi.org/10.1002/mabi.200500153

[81] Ha, E.J., Kim, Y.J., An, S.S.A., Kim, Y.R., Lee, J.O., Lee, S.G. and Paik, H.J. (2008) Purification of His-Tagged Protein Using $\mathrm{Ni}^{2+}$-Poly(2-Acetamidoacrylic Acid) Hydrogel. Journal of Chromatography B, 876, 8-12. https://doi.org/10.1016/j.jchromb.2008.10.020

[82] Stuart, M.A.C., Huck, W.T.S., Genzer, J., Müller, M., Ober, C., Stamm, M., Sukhorukov, G.B., Szleifer, I., Tsukruk, V.V., Urban, M., Winnik, F., Zauscher, S., Luzinov, I. and Minko, S. (2010) Emerging Applications of Stimuli-Responsive Polymer Materials. Nature Materials, 9, 101-113. https://doi.org/10.1038/nmat2614

[83] Tokarev, I. and Minko, S. (2009) Stimuli-Responsive Hydrogel Thin Films. Soft Matter, 5, 511-524. https://doi.org/10.1039/B813827C

[84] Wandera, D., Wickramasinghe, S.R. and Husson, S.M. (2010) Stimuli-Responsive Membranes. Journal of Membrane Science, 357, 6-35. https://doi.org/10.1016/j.memsci.2010.03.046

[85] Satarkar, N.S. and Hily, J.Z. (2008) Magnetic Hydrogel Nanocomposites for Remote Controlled Pulsatile Drug Release. Journal of Controlled Release, 130, 246-251. https://doi.org/10.1016/j.jconrel.2008.06.008

[86] Vinatier, C., Gauthier, O., Fatimi, A., Merceron, C., Masson, M., Moreau, A., Moreau, F., Fellah, B., Weiss, P. and Guicheux, J. (2009) An Injectable Cellulose-Based Hydrogel for the Transfer of Autologous Nasal Chondrocytes in Articular Cartilage Defects. Biotechnology and Bioengineering, 102, 1259-1267. https://doi.org/10.1002/bit.22137

[87] Chang, C., Duan, B., Cai, J. and Zhang, L. (2010) Superabsorbent Hydrogels Based on Cellulose for Smart Swelling and Controllable Delivery. European Polymer Journal, 46, 92-100. https://doi.org/10.1016/j.eurpolymj.2009.04.033

[88] Ye, S.H., Watanabe, J., Iwasaki, Y. and Ishihara, K. (2003) Antifouling Blood Purification Membrane Composed of Cellulose Acetate and Phospholipid Polymer. Biomaterials, 24, 4143-4152. https://doi.org/10.1016/S0142-9612(03)00296-5

[89] Sannino, A., Pappada, S., Giotta, L. and Maffezzoli, A. (2007) Spin Coating Cellulose Derivatives Onquartz Crystal Microbalance Plates to Obtain Hydrogel-Based Fast Sensors and Actuators. Journal of Applied Polymer Science, 106, 3040-3050. https://doi.org/10.1002/app.25899

[90] Ibrahim, S.M., El Salmawi, K.M. and Zahran, A.H. (2007) Synthesis of Crosslinked Superabsorbent Carboxymethyl Cellulose/Acrylamide Hydrogels through Electron-Beam Irradiation. Journal of Applied Polymer Science, 104, 2003-2008. https://doi.org/10.1002/app.25916

[91] Çaykara, T., Şengül, G. and Birlik, G. (2006) Preparation and Swelling Properties of Temperature-Sensitive Semi-Interpenetrating Polymer Networks Composed of Poly[( $N$-tert-butylacrylamide)-co-acrylamide] and Hydroxypropyl Cellulose. Macromolecular Materials and Engineering, 291, 1044-1051.

https://doi.org/10.1002/mame.200600063

[92] Zhou, D., Zhang, L. and Guo, S. (2005) Mechanism of Lead Biosorption on Cellu- 
lose/Chitin Beads. Water Research, 39, 3755-3762.

https://doi.org/10.1016/j.watres.2005.06.033

[93] Xiong, X., Zhang, L. and Wang, Y. (2005) Polymer Fractionation Using Chromatographic Column Packed with Novel Regenerated Cellulose Beads Modified with Silane. Journal of Chromatography A, 1063, 71-77.

https://doi.org/10.1016/j.chroma.2004.12.002

[94] Dang, D.L. and Dang, V.L. (1996) Chitosan-Carboxymethylcellulose Hydrogels as Supports for Cell Immobilization. Journal of Macromolecular Science, Part A: Pure and Applied Chemistry, 33, 1875-1884. https://doi.org/10.1080/10601329608011013

[95] Faroongsarng, D. and Sukonrat, P. (2008) Thermal Behavior of Water in the Selected Starch- and Cellulose-Based Polymeric Hydrogels. International Journal of Pharmaceutics, 352, 152-158. https://doi.org/10.1016/j.ijpharm.2007.10.022

[96] Hebeish, A., Higazy, A., El-Shafei, A. and Sharef, S. (2010) Synthesis of Carboxymethyl Cellulose (CMC) and Starch-Based Hybrids and Their Applications in Flocculation and Sizing. Carbohydrate Polymers, 79, 60-69.

https://doi.org/10.1016/j.carbpol.2009.07.022

[97] Isiklan, N. (2005) Controlled Release of Insecticide Carbaryl from Sodium Alginate, Sodium Alginate/Gelatin, and Sodium Alginate/Sodium Carboxymethyl Cellulose Blend Beads Crosslinked with Glutaraldehyde. Journal of Applied Polymer Science, 99, 1310-1319. https://doi.org/10.1002/app.22012

[98] Liang, H.F., Hong, M.H., Ho, R.M., Chung, C.K., Lin, Y.H., Chen, C.H. and Sung, H.W. (2004) Novel Method Using a Temperature-Sensitive Polymer (Methylcellulose) to Thermally Gel Aqueous Alginate as a pH-Sensitive Hydrogel. Biomacromolecules, 5, 1917-1925. https://doi.org/10.1021/bm049813w

[99] Sannino, A., Madaghiele, M., Conversano, F., Mele, G., Maffezzoli, A., Netti, P.A., Ambrosio, L. and Nicolais, L. (2004) Cellulose Derivative-Hyaluronic Acid-Based Microporous Hydrogels Cross-Linked through Divinyl Sulfone to Modulate Equilibrium Sorption Capacity and Network Stability. Biomacromolecules, 5, 92-96. https://doi.org/10.1021/bm0341881

[100] Hutchens, S.A., Benson, R.S., Evans, B.R., O’Neill, H.M. and Rawn, C.J. (2006) Biomimetic Synthesis of Calcium-Deficient Hydroxyapatite in a Natural Hydrogel. Biomaterials, 27, 4661-4670. https://doi.org/10.1016/j.biomaterials.2006.04.032

[101] Li, L., Meng, L., Zhang, X., Fu, C. and Lu, Q. (2009) The Ionic Liquid-Associated Synthesis of a Cellulose/SWCNT Complex and Its Remarkable Biocompatibility. Journal of Materials Chemistry Articles, 19, 3612-3617. https://doi.org/10.1039/b823322e

[102] Xia, H.F., Lin, D.Q. and Yao, S.J. (2007) Preparation and Characterization of Macroporous Cellulose-Tungsten Carbide Composite Beads for Expanded Bed Applications. Journal of Chromatography A, 1175, 55-62.

https://doi.org/10.1016/j.chroma.2007.10.004

[103] Dou, H., Yang, W., Tao, K., Li, W. and Sun, K. (2010) Thermal Sensitive Microgels with Stable and Reversible Photoluminescence Based on Covalently Bonded Quantum Dots. Langmuir, 26, 5022-5027. https://doi.org/10.1021/la903667r

[104] Luo, X., Liu, S., Zhou, J. and Zhang, L. (2009) In Situ Synthesis of $\mathrm{Fe}_{3} \mathrm{O}_{4} /$ Cellulose Micro-Spheres with Magnetic-Induced Protein Delivery. Journal of Materials Chemistry, 19, 3538-3545. https://doi.org/10.1039/b900103d

[105] Bigand, V., Pinel, C., Perez, D.D.S., Rataboul, F., Huber, P. and Petit-Conil, M. (2011) Cationisation of Galactomannan and Xylan Hemicelluloses. Carbohydrate Polymers, 85, 138-148. https://doi.org/10.1016/j.carbpol.2011.02.005 
[106] Nguyen, Q.A., Tucker, M.P., Keller, F.A. and Eddy, F.P. (2000) Two-Stage Dilute-Acid Pretreatment of Softwoods. Applied Biochemistry and Biotechnology, 84, 561-576. https://doi.org/10.1385/ABAB:84-86:1-9:561

[107] Egüés, I., Sanchez, C., Mondragon, I. and Labidi, J. (2012) Effect of Alkaline and Autohydrolysis Processes on the Purity of Obtained Hemicelluloses from Corn Stalks. Bioresource Technology, 103, 239-248. https://doi.org/10.1016/j.biortech.2011.09.139

[108] Hasegawa, I., Tabata, K., Okuma, O. and Mae, K. (2004) New Pretreatment Methods Combining a Hot Water Treatment and Water/Acetone Extraction for Thermo-Chemical Conversion of Biomass. Energy \& Fuels, 18, 755-760. https://doi.org/10.1021/ef030148e

[109] Palm, M. and Zacchi, G. (2003) Extraction of Hemicellulosic Oligosaccharides from Spruce Using Microwave Oven or Steam Treatment. Biomacromolecules, 4, 617-623. https://doi.org/10.1021/bm020112d

[110] Froschauer, C., Hummel, M., Iakovlev, M., Roselli, A., Schottenberger, H. and Sixta, H. (2013) Separation of Hemicellulose and Cellulose from Wood Pulp by Means of Ionic Liquid/Cosolvent Systems. Biomacromolecules, 14, 1741-1750. https://doi.org/10.1021/bm400106h

[111] Ebringerová, A., Hromádková, Z. and Heinze, T. (2005) Hemicellulose. In: Heinze, T., Ed., Polysaccharides I, Springer, Berlin Heidelberg, 1-67. https://doi.org/10.1007/b136816

[112] Oliveira, E.E., Silva, A.E., Junior, T.N., Gomes, M.C.S., Aguiar, L.M., Marcelino, H.R., Araujo, I.B., Bayer, M.P., Ricardo, N.M.P.S., Oliveira, A.G. and Egito, E.S.T. (2010) Xylan from Corn Cobs, a Promising Polymer for Drug Delivery: Production and Characterization. Bioresource Technology, 101, 5402-5406. https://doi.org/10.1016/j.biortech.2010.01.137

[113] Saha, B.C. (2003) Hemicellulose Bioconversion. Journal of Industrial Microbiology and Biotechnology, 30, 279-291. https://doi.org/10.1007/s10295-003-0049-x

[114] Hartman, J., Albertsson, A. and Sjoberg, J. (2006) Surface- and Bulk-Modified Galactoglucomannan Hemicellulose Films and Film Laminates for Versatile Oxygen Barriers. Biomacromolecules, 7, 1983-1989. https://doi.org/10.1021/bm060129m

[115] Hansen, N.M.L. and Plackett, D. (2008) Sustainable Films and Coatings from Hemicelluloses: A Review. Biomacromolecules, 9, 1493-1505. https://doi.org/10.1021/bm800053z

[116] Van Tuil, R. (2000) Converting Biobased Polymers into Food Packagings. Proceedings of the Food Biopack Conference, Denmark, 27-29 August 2000, 28-30.

[117] Peng, X.-W., Ren, J.-L., Zhong, L.-X., Peng, F. and Sun, R.-C. (2011) Xylan-Rich Hemicelluloses-Graft-Acrylic Acid Ionic Hydrogels with Rapid Responses to $\mathrm{pH}$, Salt, and Organic Solvents. Journal of Agricultural and Food Chemistry, 59, 8208-8215. https://doi.org/10.1021/jf201589y

[118] Voepel, J., Sjöberg, J., Reif, M., Albertsson, A.-C., Hultin, U.-K. and Gasslander, U. (2009) Drug Diffusion in Neutral and Ionic Hydrogels Assembled from Acetylated Galactoglucomannan. Journal of Applied Polymer Science, 112, 2401-2412. https://doi.org/10.1002/app.29878

[119] Ferrari, E., Ranucci, E., Edlund, U. and Albertsson, A.-C. (2015) Design of Renewable Poly(Amidoamine)/Hemicellulose Hydrogels for Heavy Metal Adsorption. Journal of Applied Polymer Science, 132, Article ID: 41695.

[120] Lin, C., Zhao, P., Li, F., Guo, F., Li, Z. and Wen, X. (2010) Thermosensitive in Situ Forming Dextran-Pluronic Hydrogels through Michael Addition. Materials Science 
and Engineering: C, 30, 1236-1244. https://doi.org/10.1016/j.msec.2010.07.004

[121] Pahimanolis, N., Kilpeläinen, P., Master, E., Ilvesniemi, H. and Seppälä, J. (2015) Novel Thiol-Amine- and Amino Acid Functional Xylan Derivatives Synthesized by Thiol-Ene Reaction. Carbohydrate Polymers, 131, 392-398. https://doi.org/10.1016/j.carbpol.2015.06.007

[122] Maleki, L., Edlund, U. and Albertsson, A.-C. (2016) Green Semi-IPN Hydrogels by Direct Utilization of Crude Wood Hydrolysates. ACS Sustainable Chemistry \& Engineering, 4, 4370-4377. https://doi.org/10.1021/acssuschemeng.6b00938

[123] Maleki, L., Edlund, U. and Albertsson, A.-C. (2017) Synthesis of Full Interpenetrating Hemicellulose Hydrogel Networks. Carbohydrate Polymers, 170, 254-263. https://doi.org/10.1016/j.carbpol.2017.04.091

[124] Zhao, W., Glavas, L., Odelius, K., Edlund, U. and Albertsson, A.C. (2014) A Robust Pathway to Electrically Conductive Hemicellulose Hydrogels with High and Controllable Swelling Behavior. Polymer, 55, 2967-2976. https://doi.org/10.1016/j.polymer.2014.05.003

[125] Zhao, W., Glavas, L., Odelius, K., Edlund, U. and Albertsson, A.C. (2014) Facile and Green Approach towards Electrically Conductive Hemicellulose Hydrogels with Tunable Conductivity and Swelling Behavior. Chemistry of Materials, 26, 4265-4273. https://doi.org/10.1021/cm501852w

[126] Zhao, W., Nugrobo, R.W.N., Odelius, K., Edlund, U., Zhao, C. and Albertsson, A.C. (2015) In Situ Cross-Linking of Stimuli-Responsive Hemicellulose Microgels during Spray Drying. ACS Applied Materials \& Interfaces, 7, 4202-4215. https://doi.org/10.1021/am5084732

[127] Yang, J.Y., Zhou, X.S. and Fang, J. (2011) Synthesis and Characterization of Temperature Sensitive Hemicellulose-Based Hydrogels. Carbohydrate Polymers, 86, 1113-1117. https://doi.org/10.1016/j.carbpol.2011.05.043

[128] Gabrielii, I. and Gatenholm, P. (2015) Preparation and Properties of Hydrogels Based on Hemicellulose. Journal of Applied Polymer Science, 69, 1661-1667. https://doi.org/10.1002/(SICI)1097-4628(19980822)69:8<1661::AID-APP19>3.0.CO $\underline{; 2-\mathrm{X}}$

[129] Guan, Y., Zhang, B., Bian, J., Peng, F. and Sun, R.-C. (2014) Nanoreinforced Hemicellulose-Based Hydrogels Prepared by Freeze-Thaw Treatment. Cellulose, 21, 1709-1721. https://doi.org/10.1007/s10570-014-0211-9

[130] Guan, Y., Bian, J., Peng, F., Zhang, X.-M. and Sun, R.-C. (2014) High Strength of Hemicelluloses Based Hydrogels by Freeze/Thaw Technique. Carbohydrate Polymers, 101, 272-280. https://doi.org/10.1016/j.carbpol.2013.08.085

[131] Meena, R., Lehnen, R., Schmitt, U. and Saake, B. (2011) Effect of Oat Spelt and Beech Xylan on the Gelling Properties of Kappa-Carrageenan Hydrogels. Carbohydrate Polymers, 85, 529-540. https://doi.org/10.1016/j.carbpol.2011.03.002

[132] Ayoub, A., Venditti, R. A., Pawlak, J. J., Salam, A. and Hubbe, M.A. (2013) Novel Hemicellulose-Chitosan Biosorbent for Water Desalination and Heavy Metal Removal. ACS Sustainable Chemical Engineering, 1, 1102-1109.

https://doi.org/10.1021/sc300166m

[133] Mano, J.F., Silva, G.A., Azevedo, H.S., Malafaya, P.B., Sousa, R.A., Silva, S.S., Boesel, L.F., Oliveira, J.M., Santos, T.C., Marques, A.P., Neves, N.M. and Reis, R.L. (2007) Natural Origin Biodegradable Systems in Tissue Engineering and Regenerative Medicine: Present Status and Some Moving Trends. Journal of the Royal Society Interface, 4, 999-1030. https://doi.org/10.1098/rsif.2007.0220

[134] Zargar, V., Asghari, M. and Dashti, A. (2015) A Review on Chitin and Chitosan 
Polymers: Structure, Chemistry, Solubility, Derivatives, and Applications. ChemBioEng Reviews, 2, 204-226. https://doi.org/10.1002/cben.201400025

[135] Zia, K.M., Barikani, M., Zuber, M., Bhatti, I.A. and Sheikh, M.A. (2008) Molecular Engineering of Chitin Based Polyurethane Elastomers. Carbohydrate Polymers, 74, 149-158. https://doi.org/10.1016/j.carbpol.2008.03.013

[136] Zia, K.M., Zuber, M., Barikani, M., Bhatti, I.A. and Khan, M.B. (2009) Surface Characteristics of Chitin-Based Shape Memory Polyurethane Elastomers. Colloids and Surfaces B: Biointerfaces, 72, 248-252. https://doi.org/10.1016/j.colsurfb.2009.04.011

[137] Ravi Kumar, M.N.V. (2000) A Review of Chitin and Chitosan Applications. Reactive and Functional Polymers, 46, 1-27. https://doi.org/10.1016/S1381-5148(00)00038-9

[138] Dutta, P.K., Dutta, J. and Tripathi, V.S. (2004) Chitin and Chitosan: Chemistry, Properties and Applications. Journal of Scientific and Industrial Research, 63, 20-31. http://nopr.niscair.res.in/handle/123456789/5397

[139] Peniche, C., Argüelles-Monal, W. and Goycoolea, F.M. (2008) Chitin and Chitosan: Major Sources, Properties and Applications. In: Gandini, A. and Belgacem, M., Eds., Monomers, Polymers, Composites Renewable Resources, Elsevier, Amsterdam, 517-542. https://doi.org/10.1016/B978-0-08-045316-3.00025-9

[140] Suh, J.K.F. and Matthew, H.W.T. (2000) Application of Chitosan-Based Polysaccharide Biomaterials in Cartilage Tissue Engineering: A Review. Biomaterials, 21, 2589-2598. https://doi.org/10.1016/S0142-9612(00)00126-5

[141] Dashtimoghadam, E., Hasani-Sadrabadi, M.M. and Moaddel, H. (2010) Structural Modification of Chitosan Biopolymer as a Novel Polyelectrolyte Membrane for Green Power Generation. Polymers for Advanced Technologies, 21, 726-734. https://doi.org/10.1002/pat.1496

[142] Bodnar, M., Hartmann, J.F. and Borbely, J. (2005) Preparation and Characterization of Chitosan-Based Nanoparticles. Biomacromolecules, 6, 2521-2527. https://doi.org/10.1021/bm0502258

[143] Valderruten, N.E, Valverde, J.D., Zuluaga, F. and Ruiz-Durántez, E. (2014) Synthesis and Characterization of Chitosan Hydrogels Cross-Linked with Dicarboxylic Acids. Reactive and Functional Polymers, 84, 21-28. https://doi.org/10.1016/j.reactfunctpolym.2014.08.006

[144] Xie, W., Xu, P., Wang, W. and Liu, Q. (2002) Preparation and Antibacterial Activity of a Water-Soluble Chitosan Derivative. Carbohydrate Polymers, 50, 35-40. https://doi.org/10.1016/S0144-8617(01)00370-8

[145] Sun, T., Xie, W. and Xu, P. (2004) Superoxide Anion Scavenging Activity of Graft Chitosan Derivatives. Carbohydrate Polymers, 58, 374-382. https://doi.org/10.1016/j.carbpol.2004.06.042

[146] Yang, S., Tirmizi, S.A., Burns, A., Barney, A.A. and Risen Jr., W.M. (1989) Chitaline Materials: Soluble Chitosan-Polyaniline Copolymers and Their Conductive Doped Forms. Synthetic Metals, 32, 191-200. https://doi.org/10.1016/0379-6779(89)90841-2

[147] De Abreu, F.R. and Campana-Filho, S.P. (2005) Preparation and Characterization of Carboxymethylchitosan. Polímeros, 15, 79-83. https://doi.org/10.1590/S0104-14282005000200004

[148] Jayakumar, R., Selvamurugan, N., Nair, S.V., Tokura, S. and Tamura, H. (2008) Preparative Methods of Phosphorylated Chitin and Chitosan-An Overview. International Journal of Biological Macromolecules, 43, 221-225. 
https://doi.org/10.1016/j.ijbiomac.2008.07.004

[149] Badawy, M.E., Rabea, E.I., Rogge, T.M., Stevens, C.V., Smagghe, G., Steurbaut, W. and Höfte, M. (2004) Synthesis and Fungicidal Activity of New N,O-Acyl Chitosan Derivatives. Biomacromolecules, 5, 589-595. https://doi.org/10.1021/bm0344295

[150] Gorochovceva, N. and Makuška, R. (2004) Synthesis and Study of Water-Soluble Chitosan-O-Poly(Ethylene Glycol) Graft Copolymers. European Polymer Journal, 40, 685-691. https://doi.org/10.1016/j.eurpolymj.2003.12.005

[151] Fajardo, A.R., Lopes, L.C., Valente, A.J.M., Rubira, A.F. and Muniz, E.C. (2011) Effect of Stoichiometry and $\mathrm{pH}$ on the Structure and Properties of Chitosan/Chondroitin Sulfate Complexes. Colloid and Polymer Science, 289, 1739-1748. https://doi.org/10.1007/s00396-011-2497-6

[152] Fajardo, A.R., Piai, J.F., Rubira, A.F. and Muniz, E.C. (2010) Time and $\mathrm{pH}$-Dependent Self-Rearrangement of a Swollen Polymer Network Based on Polyelectrolytes Complexes of Chitosan/Chondroitin Sulfate. Carbohydrate Polymers, 80, 934-943. https://doi.org/10.1016/j.carbpol.2010.01.009

[153] Kim, J., Cai, Z., Lee, H.S., Choi, G.S., Lee, D.H. and Jo, C. (2011) Preparation and Characterization of Bacterial Cellulose/Chitosan Composite for Potential Biomedical Application. Journal of Polymer Research, 18, 739-744.

https://doi.org/10.1007/s10965-010-9470-9

[154] Kim, S.J., Shin, S.R., Lee, S.M., Kim, I.Y. and Kim, S.I. (2004) Electromechanical Properties of Hydrogels Based on Chitosan and Poly(Hydroxyethyl Methacrylate) in $\mathrm{NaCl}$ Solution. Smart Materials and Structures, 13, 1036-1039. https://doi.org/10.1088/0964-1726/13/5/008

[155] Lee, C.K., Kim, S.J., Kim, S.I., Yi, B.J. and Han, S.Y. (2006) Preparation of Chitosan Microfibers Using Electro-Wet-Spinning and Their Electroactuation Properties. Smart Materials and Structures, 15, 607-611. https://doi.org/10.1088/0964-1726/15/2/044

[156] Twu, Y.K., Huang, H.I., Chang, S.Y. and Wand, S.L. (2003) Preparation and Sorption Activity of Chitosan/Cellulose Blend Beads. Carbohydrates Polymers, 54, 425-430. https://doi.org/10.1016/j.carbpol.2003.03.001

[157] Cai, Z. and Kim, J. (2009) Cellulose-Chitosan Interpenetrating Polymer Network for Electro-Active Paper Actuator. Journal of Applied Polymer Science, 114, 288-297. https://doi.org/10.1002/app.30456

[158] Sarasam, A.R., Krishnaswamy, R.K. and Madihally, S.V. (2006) Blending Chitosan with Polycaprolactone: Effects on Physicochemical and Antibacterial Properties. Biomacromolecules, 7, 1131-1138. https://doi.org/10.1021/bm050935d

[159] Yin, L., Fei, L., Cui, F., Tang, C. and Yin, C. (2007) Superporous Hydrogels Containing Poly(Acrylic Acid-co-Acrylamide)/O-Carboxymethyl Chitosan Interpenetrating Polymer Networks. Biomaterials, 28, 1258-1266. https://doi.org/10.1016/j.biomaterials.2006.11.008

[160] Sun, J. and Tan, H. (2013) Alginate-Based Biomaterials for Regenerative Medicine Applications. Materials, 6, 1285-1309. https://doi.org/10.3390/ma6041285

[161] Thakur, S., Sharma, B., Verma, A.J., Chaudhary, J., Tamulevicius, S. and Thakur, V.K. (2018) Recent Progress in Sodium Alginate Based Sustainable Hydrogels for Environmental Applications. Journal of Cleaner Production, 198, 143-159. https://doi.org/10.1016/j.jclepro.2018.06.259

[162] Pedrosa, P., Fiedler, P., Schinaia, L., Vasconcelos, B., Martins, A.C., Amaral, M.H., Comani, S., Haueisen, J. and Fonseca, C. (2017) Alginate-Based Hydrogels as an 
Alternative to Electrolytic Gels for Rapid EEG Monitoring and Easy Cleaning Procedures. Sensors and Actuators B, 247, 273-283.

https://doi.org/10.1016/j.snb.2017.02.164

[163] Yang, J.S., Xie, Y.J. and He, W. (2011) Research Progress on Chemical Modification of Alginate: A Review. Carbohydrate Polymers, 84, 33-39.

https://doi.org/10.1016/j.carbpol.2010.11.048

[164] Boontheekul, T., Kong, H. and Mooney, D. (2005) Controlling Alginate Gels Degradation Utilizing Partial Oxidation and Bimodal Molecular Weight Distribution. Biomaterials, 26, 2455-2465. https://doi.org/10.1016/j.biomaterials.2004.06.044

[165] Gomez, C.G., Rinaudo, M. and Villar, M.A. (2007) Oxidation of Sodium Alginate and Characterization of the Oxidized Derivatives. Carbohydrate Polymers, 67, 296-304. https://doi.org/10.1016/j.carbpol.2006.05.025

[166] Fan, L., Jiang, L., Xu, Y., Zhou, Y., Shen, Y., Xie, W., et al. (2011) Synthesis and Anticoagulant Activity of Sodium Alginate Sulfates. Carbohydrate Polymers, 83, 1797-1803. https://doi.org/10.1016/j.carbpol.2010.10.038

[167] Ronghua, H., Yumin, D. and Jianhong, Y. (2003) Preparation and in Vitro Anticoagulant Activities of Alginate Sulfate and Its Quaterized Derivatives. Carbohydrate Polymers, 52, 19-24. https://doi.org/10.1016/S0144-8617(02)00258-8

[168] Kang, H., Jeon, G., Lee, M. and Yang, J. (2002) Effectiveness Test of Alginate-Derived Polymeric Surfactants. Journal of Chemical Technology and Biotechnology, 77, 205-210. https://doi.org/10.1002/jctb.550

[169] Yu, Y., Leng, C., Liu, Z., Jia, F., Zheng, Y., Yuan, K. and Yan, S. (2014) Preparation and Characterization of Biosurfactant Based on Hydrophobically Modified Alginate. Colloid Journal, 76, 622-627. https://doi.org/10.1134/S1061933X14050160

[170] Liu, M.Z. and Cao, L.X. (2002) Preparation of a Superabsorbent Resistant to Saline Solution by Copolymerization of Acrylic Acid with Sodium Polymannuronate. Chinese Journal of Applied Chemistry, 19, 455-458.

[171] Sen, G., Singh, R.P. and Pal, S. (2010) Microwave-Initiated Synthesis of Polyacrylamide Grafted Sodium Alginate: Synthesis and Characterization. Journal of Applied Polymer Science, 115, 63-71. https://doi.org/10.1002/app.30596

[172] Sand, A., Yadav, M. and Behari, K. (2010) Synthesis and Characterization of Alginate- $g$-Vinyl Sulfonic Acid with a Potassium Peroxydiphosphate/Thiourea System. Journal of Applied Polymer Science, 118, 3685-3694. https://doi.org/10.1002/app.32447

[173] Leonard, M., Rastello De Boisseson, M., Hubert, P., Dalencon, F. and Dellacherie, E. (2004) Hydrophobically Modified Alginate Hydrogels as Protein Carriers with Specific Controlled Release Properties. Journal of Controlled Release, 98, 395-405. https://doi.org/10.1016/j.jconrel.2004.05.009

[174] Broderick, E., Lyons, H., Pembroke, T., Byrne, H., Murray, B. and Hall, M. (2006) The Characterisation of a Novel Covalently Modified, Amphiphilic Alginate Derivative, Which Retains Gelling and Non-Toxic Properties. Journal of Colloid and Interface Science, 298, 154-161. https://doi.org/10.1016/j.jcis.2005.12.026

[175] Yan, H., Chen, X., Li, J., Feng, Y., Shi, Z., Wang, X., et al. (2016) Synthesis of Alginate Derivative via the Ugi Reaction and Its Characterization. Carbohydrate Polymers, 136, 757-763. https://doi.org/10.1016/j.carbpol.2015.09.104

[176] Yin, L., Fei, L., Tang, C. and Yin, C. (2007) Synthesis, Characterization, Mechanical Properties and Biocompatibility of Interpenetrating Polymer Network-Super-Porous Hydrogel Containing Sodium Alginate. Polymer International, 56, 1563-1571. 
https://doi.org/10.1002/pi.2306

[177] Omidian, H., Rocca, J.G. and Park, K. (2006) Elastic, Superporous Hydrogel Hybrids of Polyacrylamide and Sodium Alginate. Macromolecular Bioscience, 6, 703-710. https://doi.org/10.1002/mabi.200600062 